\title{
Vegetation types of the upper Madeira River in Rondônia, Brazil
}

\author{
Natália Alves Perigolo ${ }^{1}$, Marcelo Brilhante de Medeiros², and \\ Marcelo Fragomeni Simon ${ }^{2}$
}

${ }^{1}$ Programa de Pós-Graduação em Botânica, Departamento de Botânica, Instituto de Ciências Biológicas, Campus Universitário Darcy Ribeiro, Universidade de Brasília, Caixa Postal 4457, Brasília, DF 70919-970, Brazil; e-mail: nperigolo@gmail.com

${ }^{2}$ Embrapa Recursos Genéticos e Biotecnologia, Parque Estação Biológica (PqEB), Av. W5 Norte (final), Asa Norte, Caixa Postal 2372, Brasília, DF 70770-917, Brazil; e-mail: marcelo.brilhante@embrapa.br; e-mail: marcelo.simon@embrapa.br

\begin{abstract}
We characterize the vegetation types of the upper basin of the Madeira River in the Brazilan state of Rondônia, a biodiverse region with elevated rates of habitat loss. Vegetation and environmental parameters were recorded from 37 observation points distributed along and near a $160 \mathrm{~km}$ stretch of the Madeira River and representing the range of regional environments. Analysis of structure and floristic variables, as well as associated edaphic attributes and water table fluctuation, permitted recognition of five main vegetation types and seven subtypes. Open Ombrophilous Forest was the most frequently encountered vegetation type and occurred on well-drained, nutrient-poor soils, whereas Dense Ombrophilous Forest was seldom recorded. Alluvial Ombrophilous Forests (várzea) were found along a narrow strip of land along the banks of the Madeira River on the most fertile soils in the study area. Semideciduous Forests were found on small areas of rocky outcrops with shallow soils and reduced water availability during the dry season. Campinaranas, which range from open savanna physiognomies to closed canopy forests, were found to be a key environment in the lowlands south of the Madeira River on silty hydromorphic soils, where they harbor a peculiar flora tolerant of flooding during the rainy season. Our classification of the main vegetation types in the upper Madeira River illuminates a high degree of floristic and environmental heterogeneity in a highly threatened region. Our results will be useful for designing conservation strategies aimed at protecting the full range of floristic diversity present in the region.
\end{abstract}

Keywords: Amazon, Campinarana, Soil fertility, Terra firme forest, Várzea, Water table.

Resumo. Caracterizamos os tipos de vegetação do alto rio Madeira no estado de Rondônia, uma região biodiversa mas com taxas elevadas de perda de habitat. Parâmetros de vegetação e ambientais foram registrados em 37 pontos de observação distribuídos ao longo de um trecho de $160 \mathrm{~km}$ do rio Madeira, representando a gama de ambientes da região. A análise das variáveis estruturais e florísticas, bem como dos atributos edáficos associados e a flutuação do lençol freático, permitiram o reconhecimento de cinco principais tipos de vegetação e sete subtipos. A Floresta Ombrófila Aberta foi o tipo de vegetação mais freqüentemente encontrado e ocorreu em solos bem drenados e pobres em nutrientes, enquanto que a Floresta Ombrófila Densa foi raramente registrada. As Florestas Aluviais (várzea) foram encontradas ao longo de uma estreita faixa de terra ao longo das margens do rio Madeira, nos solos mais férteis da área de estudo. As Florestas Semidecíduas foram encontradas em pequenas áreas de afloramentos rochosos com solos pouco profundos e disponibilidade de água reduzida durante a estação seca. As Campinaranas, que variam de fisionomias de savana aberta a floresta de dossel fechado, constituem-se em um ambiente chave nas terras baixas ao sul do rio Madeira, em solos siltosos, hidromórficos, e abrigam uma flora peculiar, tolerante às inundações 
durante a estação chuvosa. Nossa classificação dos principais tipos de vegetação no alto rio Madeira revela um alto grau de heterogeneidade florística e ambiental em uma região altamente ameaçada. Nossos resultados serão úteis para a elaboação de estratégias de conservação destinadas a proteger toda a gama de diversidade florística presente na região.

Despite its reputation as an area covered by homogeneous rainforest, lowland Amazonia encompasses a wide variety of landscapes and vegetation types, which individually harbor rich and often exclusive associated floras (Ducke \& Black, 1954; Pires \& Prance, 1985; Daly \& Mitchell, 2000). Climate is relatively uniform in the region, but variation in annual precipitation and the duration of the dry season is associated with spatial variation in the vegetation (Eiten, 1992; ter Steege et al., 2006). In addition to climate, soil gradients (texture and fertility), drainage, and topography (elevation and slope) are important drivers of floristic composition and biomass at different spatial scales (Castilho et al., 2006; Bohlman et al., 2008), resulting in different vegetation types.

Vegetation types in Amazonia include both forested and non-forested formations. Forests cover most of the region and are classified into two broad categories: non-flooded (terra firme) and flooded forests (Pires \& Prance, 1985). Terra firme forests vary in structure and floristic composition, allowing for subdivision into dense and open forest types (Pires \& Prance, 1985). The open terra firme forest can be further divided depending on the predominance of associated elements such as palms or bamboo, which brings to each of these forest types a particular physiognomy (IBGE, 2012). Flooded forests occupy areas adjacent to major rivers and can be classified as várzea or igapó. Várzea forests are periodically flooded by rivers that carry clay-rich sediments (white-water systems), while igapó forests are associated with sediment-poor rivers (black or clear-water systems), normally occurring on sandy soils (Braga, 1979; Prance, 1980). Várzea forests have higher soil fertility and species richness, whereas igapó forests grow on nutrient-poor soils and are less diverse (Junk et al., 2011). Non-forested vegetation types are distributed discontinuously in Amazonia, thus conferring habitat heterogeneity in a forest-dominated landscape. The main types of non-forested physiognomies are campinaranas, campinas, caatingas, upland savannas and campos rupestres (Pires, 1973; Pires \& Prance, 1985; IBGE, 2012; Adeney et al., 2016).
Intensive floristic studies have occurred mainly near large cities such as Belém and Manaus in Brazil and Iquitos in Peru, but most of Amazonia has been surveyed poorly or not at all (Hopkins, 2007; Sousa-Baena et al., 2014). This inhibits understanding of structural patterns and regional differences in terms of vegetation types and species composition (e.g., Milliken et al., 2010). While exceptionally high levels of alpha diversity have been well documented in Amazonian plant communities (Oliveira, 2000; ter Steege et al., 2006), plant species turnover accross Amazonian landscapes (i.e., beta diversity) has been much less studied.

Stretching from southwestern to central Amazonia, the Madeira River basin accounts for about $20 \%$ of the total Amazon basin. It harbors a wide variety of environments such as upland and floodplain forests, campinaranas, savannas, swamps and grasslands (Cochrane \& Cochrane, 2006; Py-Daniel, 2007; Moser et al., 2014). Despite its size and high beta-diversity, the Madeira River basin is one of the least studied in the Amazon. Rapid development in the region over the last 30 years, particularly in the upper Madeira basin in Rondônia, has posed a major threat to a number of natural habitats (Ferraz et al., 2005). Agricultural colonization and large-scale deforestation - and more recently, the building of hydroelectric dams and infrastructure projects - have affected native vegetation at a much faster pace than biological surveys are carried out (e.g., Carleial \& Bígio, 2014). Considering the lack of botanical studies focused on the landscapes of the upper Madeira, and the high levels of environmental threats experienced in this region, efforts towards documenting its vegetation and flora should be a priority. Here we investigate the main vegetation types that occur along the upper Madeira River in Rondônia. We describe structural aspects and the major floristic elements, as well as associated edaphic and drainage attributes that distinguish each physiognomy. 


\section{Materials and methods}

\section{STUDY AREA}

The study was conducted along a stretch of approximately $160 \mathrm{~km}$ of the upper Madeira River between the districts of Abunã and Jaci-Paraná in northern Rondônia (Fig. 1), the site of previous floristic and ecological studies in the area affected by the Jirau hydroelectric dam (e.g., Moser et al., 2014; Catenacci \& Simon, 2017). The climate in the region is tropical humid hyperthermic, with five months experiencing less than $100 \mathrm{~mm}$ rain (May-September), average temperatures around $26^{\circ} \mathrm{C}$ and annual rainfall between 1700 and $2000 \mathrm{~mm}$ (Cochrane \& Cochrane, 2006; ANA, 2014). These climatic conditions fall within the limits of the Am and Aw categories of the Köppen system (Kottek et al., 2006).

The relief of the region is flat, mostly around $100 \mathrm{~m}$ elevation, but on the left bank (facing downstream) north of the Madeira River, the elevation may exceed $300 \mathrm{~m}$. In the study area, each side of the Madeira River represents a different type of geological formation. The left side is characterized by igneous and metamorphic rocks of Pre-Cambrian origin (ca. 1.5 billion years old). In contrast, the floodplains of the right side comprise
Pliocene-Pleistocene formations $<3.6$ million years old, as well as much more recent alluvial deposits $<10,000$ years old (RADAMBRASIL, 1978). Dystrophic well-drained oxisols predominate along the left bank, whereas haplic gleysol dystrophic soils occur on the poorly-drained plains of the right bank between the districts of Abunã and Mutum-Paraná, as well as oxisols in welldrained areas (RADAMBRASIL, 1978; Cochrane \& Cochrane, 2006). The right margin of the Madeira has been strongly affected by deforestation, agriculture and road building (Fig. 1), while the left margin is better preserved and includes the 1.8 million ha Mapinguari National Park.

\section{Data COLLECTION AND ANALYSIS}

Field surveys employed the Rapid Ecological Assessment protocol of Sayre et al. (2003), a quick survey method aimed at characterizing the main species and vegetation types of a given area. We sampled 37 observation points (i.e., discrete localities) aiming at covering the extent of the study area and its variety of environments. Most observation points were arranged along transects perpendicular to the river, which were used for

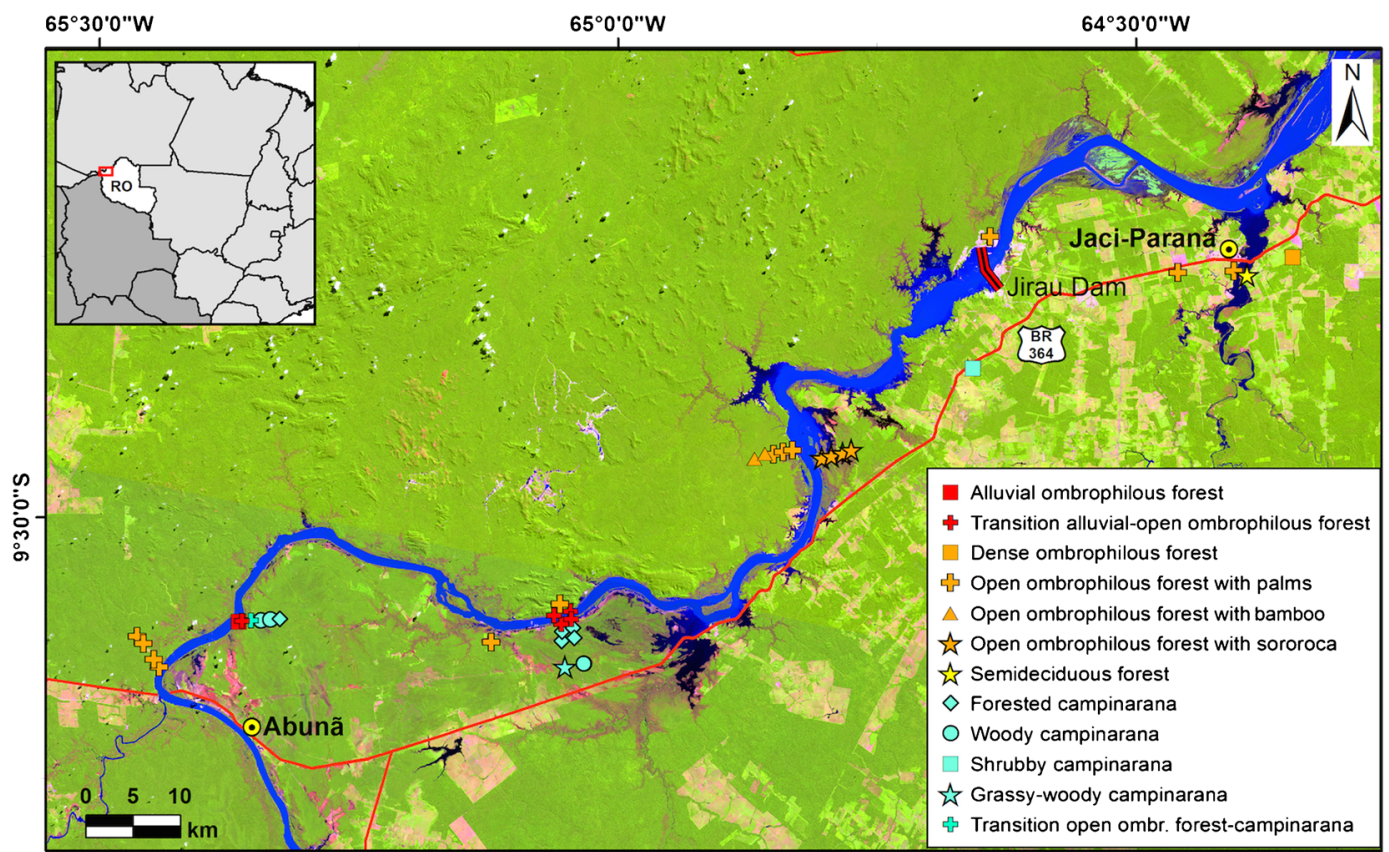

Fig. 1. Study area in the region of the upper Madeira River in northern Rondônia, Brazil. Symbols represent observation points surveyed and their respective vegetation types. Background Landsat 8 image from 18/06/2014 (Source: USGS). 
monitoring the vegetation in the study area (see Moser et al., 2014), while other observation points were choosen because of the presence of particular vegetation types or easy access by road (Fig. 1). At each observation point, we recorded basic environmental parameters (geo-coordinates, relief, topography, slope, drainage and rockiness), water table depth, soil properties, vegetation structure, canopy openness, and dominant species by stratum. Classification of vegetation types was based mainly on the IBGE (2012) system, and characterization was based on field observations and validated using cluster analysis of species occurrence data (see below). Vouchers of species found at the observation points were collected and deposited in the CEN herbarium.

Canopy openness was estimated in May 2014 using hemispherical photography, with a digital camera fitted with a $15 \mathrm{~mm}$ fisheye lens. The average of canopy openness for each observation point was calculated from four photographs taken at least $10 \mathrm{~m}$ apart. The photos were turned into two-tone (black and white, 8 bits) in Adobe Photoshop 13.0, and the percentage of open canopy area was measured using the software ImageJ 1.48v (Abramoff et al., 2004). Water table measurements were carried out using piezometers, with measurements taken every $30 \mathrm{~min}$ from June 2012 to June 2013 and stored in a data logger. Piezometers were installed at 24 of the 35 observation points, and the remaining observation points were visually classified as either well-drained or seasonally flooded.

Two to six soil samples were collected at each observation point. Each sample was composed of four sub-samples from depths of $0-5,5-10,10-20$ and $20-30 \mathrm{~cm}$, after removal of the surface organic layer. The sub-samples were stored at room temperature until completly dry. For each observation point, sub-samples of the same depth were homogenized. Samples were then sent for physicalchemical analysis in the laboratory following the protocol of EMBRAPA (1997). The soil analysis included texture (sand, clay, silt) and chemical $\left(\mathrm{pH}, \mathrm{Ca}^{2+}, \mathrm{K}^{+}, \mathrm{Mg}^{2+}, \mathrm{Na}^{+}, \mathrm{Al}^{3+}, \mathrm{C}, \mathrm{N}, \mathrm{P}\right)$ parameters. For the purpose of analysis, averages calculated from across the four depths (subsamples) were used to represent physical and chemical variables. A principal component analysis (PCA) was performed to reduce the dimensionality of the soil variables at each observation point, and to identify possible associations between vegetation types and soil parameters. Soil data were standardized to the same relative scale Z-score
(Gotelli \& Ellison, 2012), and the PCA was performed in the program R ( $\mathrm{R}$ Development Core Team, 2014) using the bpca package (Faria \& Demetrio, 2011). Some of our observation points coincided with flora monitoring plots already established in the study area (Moser et al., 2014), for which there are detailed data on composition and structure of vegetation, texture and fertility of soil and variation in groundwater level. This information was included in our analyses.

\section{COMPARISONS AMONG OBSERVATION POINTS}

Floristic similarity between observation points was examined using a species presence/absence matrix. This data matrix was built using the ten most abundant species at each observation point. It included mostly tree species (forest formations), but also shrubs and herbs where they predominate (e.g., open campinarana). The Jaccard Index was used to calculate a dissimilarity matrix for all observation points. Clustering analysis performed on the dissimilarity matrix employed UPGMA (Unweighted Pair Group Method with Arithmetic; Sneath \& Sokal, 1973). The resulting dendrogram, in conjunction with field observations, enabled us to classify the different vegetation types found in the study area. Analyses were conducted using the vegan package (Oksanen et al. 2016) in $R$ ( $R$ Development Core Team, 2014).

\section{Results and discussion-General characterization of vegetation in the upper Madeira}

Overall, the study area showed a markedly heterogeneous landscape. The 37 observation points sampled were classified into a total of ten vegetation types, comprising five main types and seven subtypes (Figs. 2, 3; Table 1): Alluvial Ombrophilous Forest, Dense Lowland Ombrophilous Forest, Open Lowland Ombrophilous Forest (including three subtypes), Lowland Semideciduous Forest, and Campinarana (including four subtypes). [The term "Lowland" will be omitted hereafter when referring to vegetation types.] Six observation points were classified as transitional between different vegetation types (Table 1). Open Ombrophilous Forest was the most frequently encountered vegetation type. It was divided into three subtypes: with palms (the most common subtype), with sororoca (Phenakospermum guyannense), and with bamboo. 

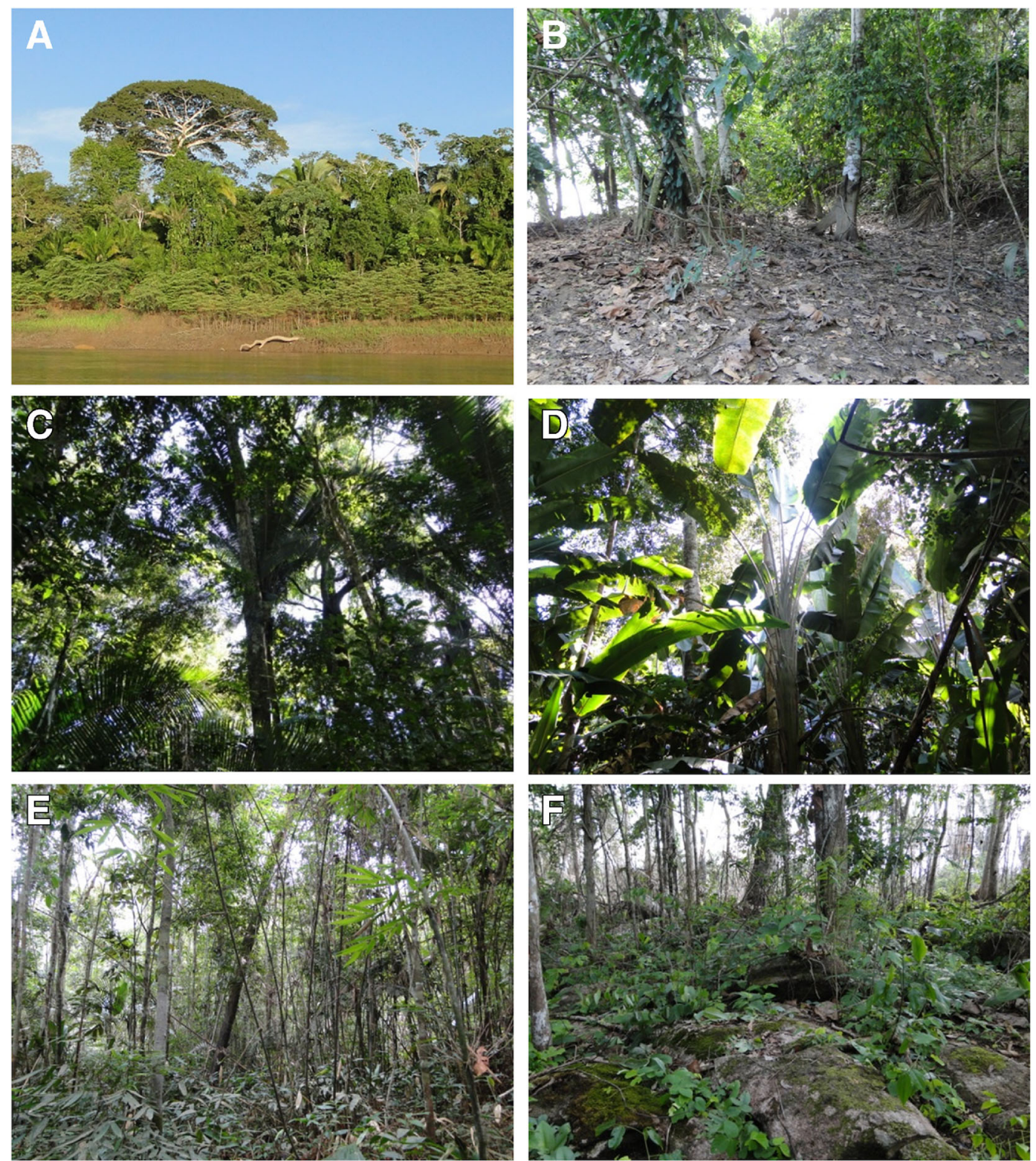

Fig. 2. Vegetation types in the upper Madeira region. A. Alluvial Ombrophilous Forest (várzea). B. Upper várzea during dry season. C. Open Ombrophilous Forest with palms. D. Open Ombrophilous Forest with sororoca. E. Open Ombrophilous Forest with bamboo. F. Semidecidous Forest (wet season) growing on rocky soil. Photos: N. A. Perígolo.

Dense Ombrophilous Forest was less frequent, being recorded at only one observation point. Alluvial Ombrophilous Forest (várzea) and transitions to Open Ombrophilous Forest were found along the Madeira, whereas Semideciduous Forest occurred as small patches growing on rocky outcrops. Campinaranas belonging to four different subtypes occurred in the flat lowlands on the right bank of the Madeira (Fig. 1). The vegetation types surveyed showed structural variation ranging from an average canopy height of $25 \mathrm{~m}$ in Dense Ombrophilous Forest to the absence of trees in Grassy-Woody Campinarana (Figs. 2, 3). Canopy openness varied widely among vegetation types (Table 1). Deciduousness was observed only in the Semideciduous Forest.

Water table levels rose rapidly from November, soon after the start of the rainy season, and 

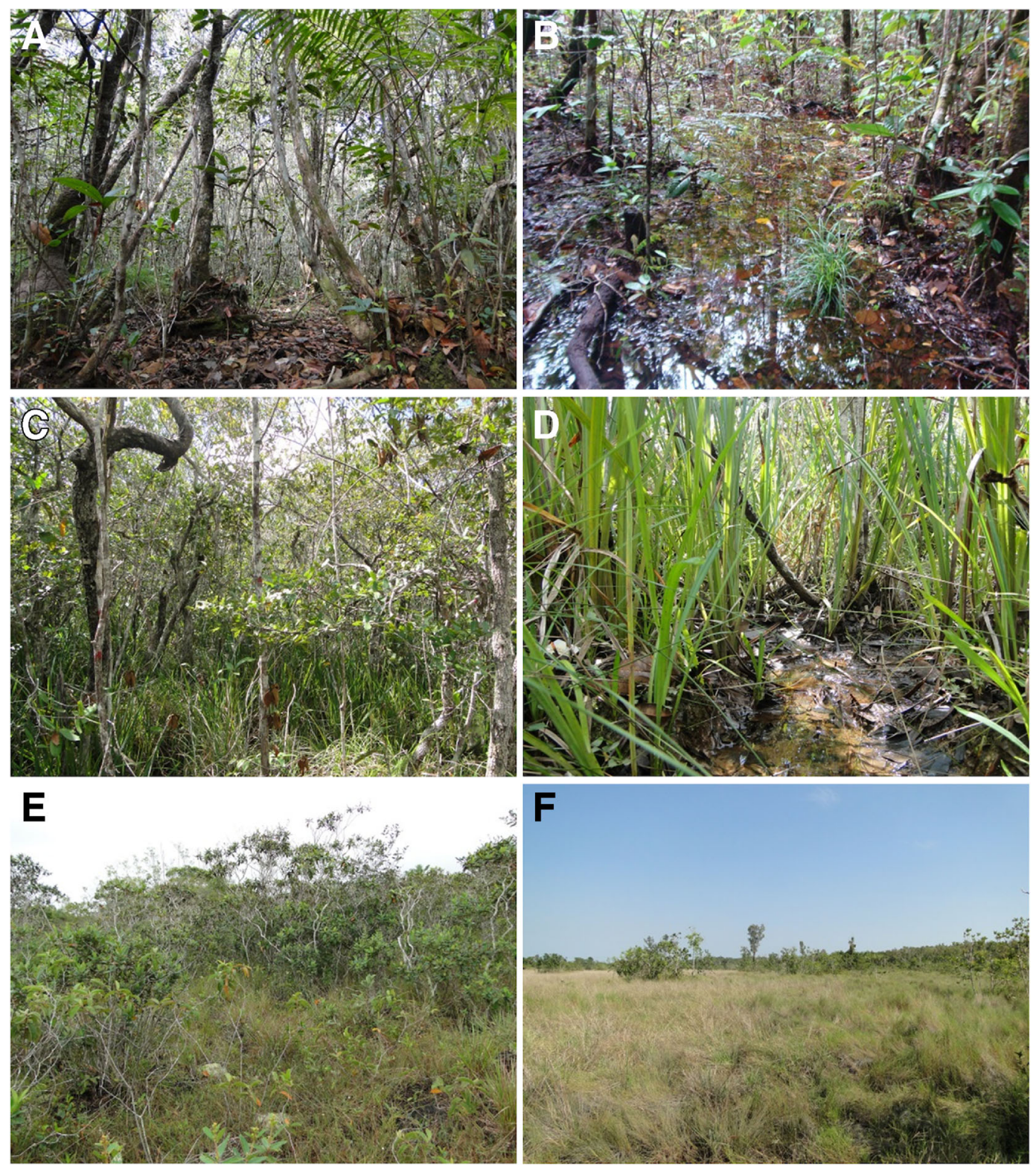

Fig. 3. Vegetation types in the upper Madeira region continued. A. Forested Campinarana. B. Detail of Forested Campinarana during wet season flooding. C. Wooded Campinarana. D. Detail of herbaceous layer in Wooded Campinarana. E. Shrubby Campinarana. F. Grassy-woody Campinarana. Photos: N.A. Perígolo.

remained high until May, followed by a gradual reduction from June to October (Fig. 4). While this general pattern was apparent across sites, unique patterns of variation in water table levels were observed among vegetation types. Open Ombrophilous Forest displayed relatively deep water table levels, whereas campinaranas were found to have more superficial water tables subject to ca. five months of seasonal flooding during the rainy season. Within Open Ombrophilous Forest, the subtype with palms showed the lowest annual variation in water table levels, while the subtype with bamboo had both the highest amplitude and the most superficial levels (Fig. 4).

Soil samples showed wide variation in texture, $\mathrm{pH}$, concentration of $\mathrm{Al}^{+3}, \mathrm{C}, \mathrm{N}$ and sum of exchangeable bases (Appendix 1). The PCA displayed marked separation of observation 


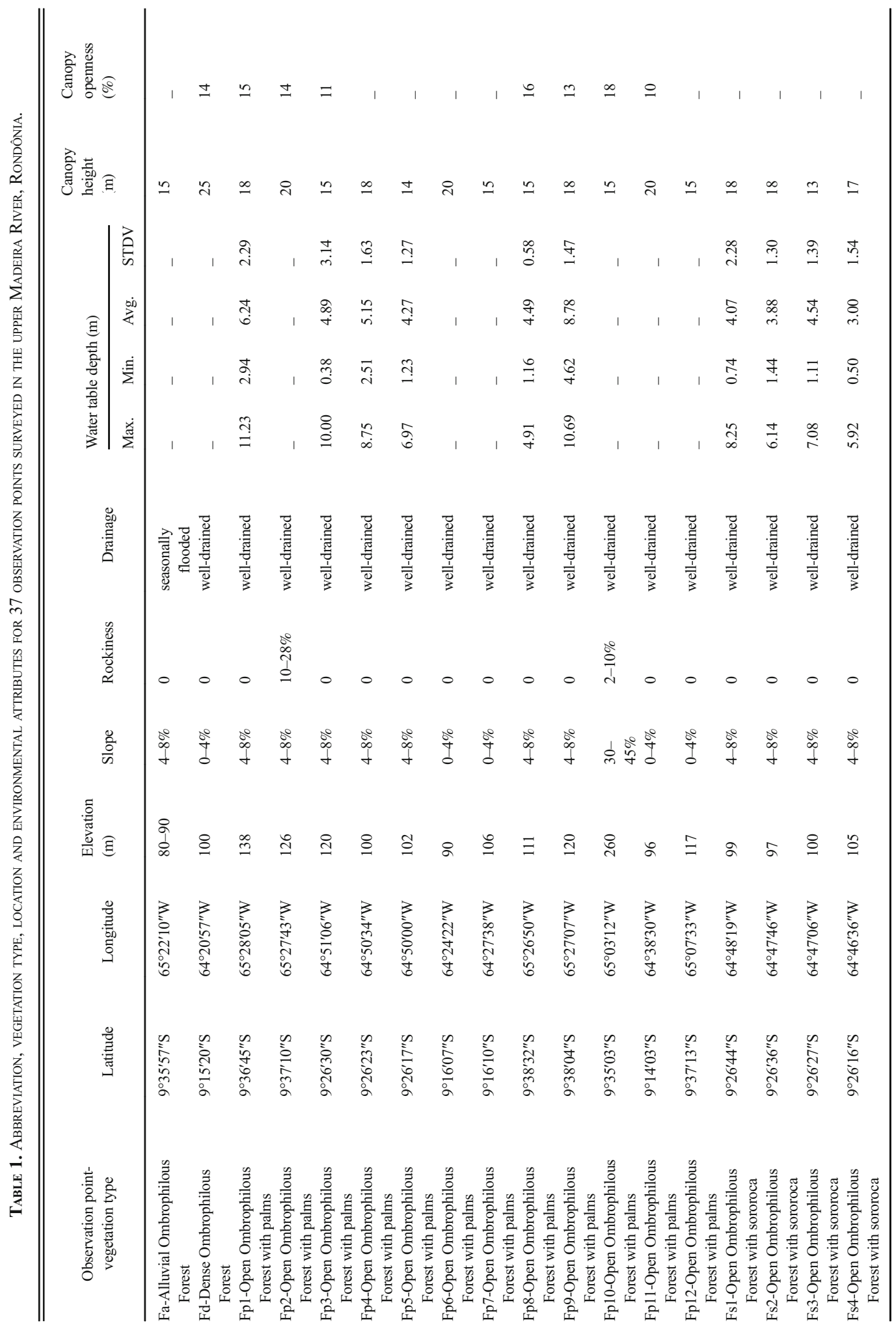




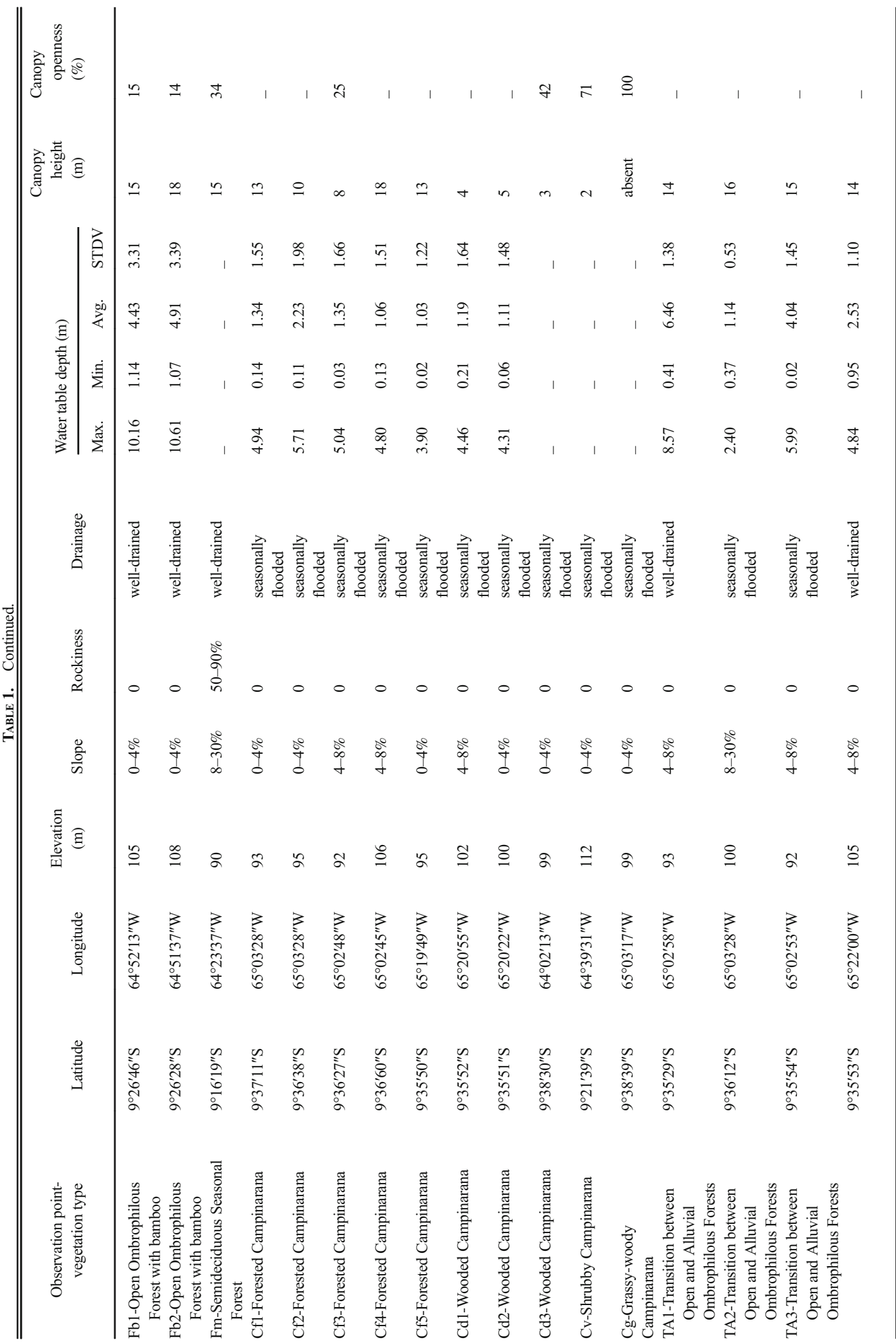


points based on soil parameters and revealed an overall congruence between vegetation type and soil fertility and texture (Fig. 5). Alluvial Ombrophilous Forest stood out for having the most fertile soils, with higher $\mathrm{pH}$, sum of bases, and phosphorus concentration, but the lowest aluminum levels (Appendix 1). Open Ombrophilous Forest exhibited wide ranges for soil texture and fertility, but in general soils supporting this vegetation type tended to be more acidic and of clay-sandy texture. Soils supporting the subtype with sororoca were comparatively less acidic and had a higher proportion of silt, whereas soils suppporting the subtype with bamboo tended to have clayey texture and higher concentrations of aluminium. Soils supporting Semideciduous Forest had claysandy texture and intermediate fertility, but a high degree of rockiness, whereas soils supporting Dense Ombrophilous Forest had low-fertility, high sand content, and low $\mathrm{pH}$. Soils supporting campinarana generally showed relatively high silt content and higher $\mathrm{pH}$ and $\mathrm{N}$, with a gradient of these parameters from Forested to Open Campinaranas. An outlier point among campinaranas was Shrubby Campinarana, which had soil with higher proportions of sand, low $\mathrm{pH}$ and low $\mathrm{N}$ (Appendix 1; Fig. 5).

The vegetation types surveyed showed significant differences in floristic composition, which allowed the recognition of suites of characteristic species associated with each physiognomy: Attalea speciosa, Eschweilera coriacea, Protium paniculatum in Open Ombrophilous Forest; Ceiba pentandra, Gustavia poeppigiana, Hura crepitans, Maquira coriacea, Martiodendron elatum and Schizolobium parahyba in Alluvial Ombrophilous Forest and transitional areas; Astronium sp., Cedrela fissilis, Handroanthus serratifolius and Hymenaea courbaril in semideciduous forest; and Byrsonima spp., Clusia sp., Euterpe precatoria, Henriettea granulata, Iryanthera spp., Pera spp., Ruizterania retusa, and Xylopia neglecta in Forested and Wooded Campinaranas. A list containing occurrence data for 180 species in 12 vegetation types, along with full species names and herbarium vouchers, is presented in Appendix Table 2. The classification of the vegetation types based on field observations was largely corroborated by cluster analysis (Fig. 6), in which observation points were grouped 


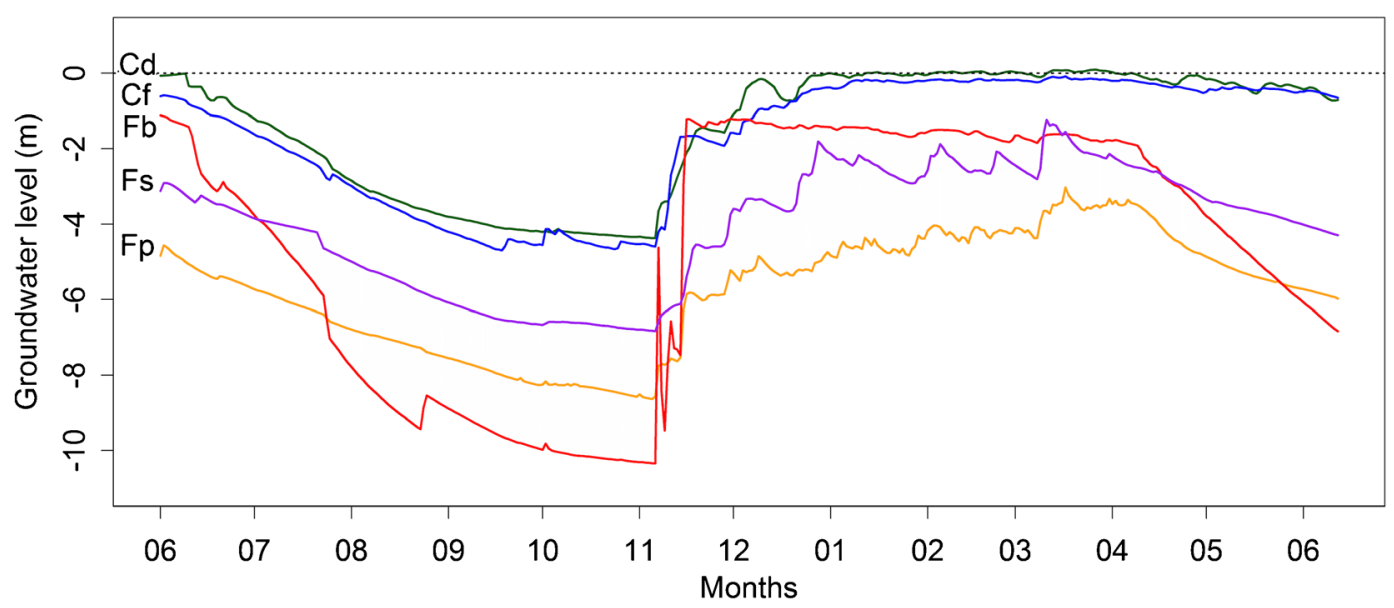

Fig. 4. Water table levels in five vegetation types in the upper Madeira region (data from June 2012 to June 2013). Each line corresponds to averaged data within each vegetation type. Fp: Open Ombrophilous Forest with palms (observation points Fp1, Fp3, Fp4, Fp5, Fp8, Fp9). Fs: Open Ombrophilous Forest with sororoca (observation points Fs1-Fs4). Fb: Open Ombrophilous Forest with bamboo (observation points Fb1-Fb2). Cf: Forested Campinarana (Cf1-Cf5). Cd: Wooded Campinarana (Cd1-Cd2). See also Table 1.

based on the occurrence of the most common species. Major clusters included Campinaranas, Alluvial and Open Ombrophilous Forests.

\section{Descriptions of the principal vegetation types of the upper Rio Madeira}

\section{Alluvial Ombrophilous Forest (Floresta OMbrófila Aluvial, vÁrzea fOrest)}

The upper Madeira has a very deep channel and high riverbanks, and the floodplain is much more narrow than in many other parts of Amazonia where várzea systems are developed (Junk et al., 2011). In the study area, Alluvial Ombrophilous Forest (Fig. 2A, B) occupies a narrow $(10-20 \mathrm{~m})$ zone along the banks of the river. This zone is influenced by seasonal flooding as a result of $10 \mathrm{~m}$ variation in river levels between periods of flood and drought. Soils in Alluvial Ombrophilous Forest had the highest measured fertility levels, apparently resulting from the annual deposition of nutrientrich sediments by the river. The terrain where this vegetation type occurs is steep, with the lower part more exposed to river currents and subject to erosion and sediment deposition. Soils supporting this vegetation type were collected on both the lowest and highest parts of the river bank, with the two collecting points showing similar characteristics but the upper with slightly higher fertility (symbols Fal and $\mathrm{Fa} 2$ in Fig. 5). Transitional areas between
Alluvial and Open Ombrophilous Forest that occur adjacent to the banks of the Madeira River (Fig. 1) are less prone to seasonal flooding and have intermediate levels of fertility (Fig. 5; Appendix 1).

During low-water periods, the lower part of the banks of the Madeira are exposed and colonized by annual herbs such as Echinochloa sp. In the intermediate zone further up the slope, the tall grass Gynerium sagittatum predominates, forming clumps on the riverbank. There are also a few tree species that establish in this zone, including Albizia niopoides, Cecropia spp., Muntingia calabura, and Inga spp. The highest zone of the varzea is less affected by inundation. It has a canopy height of ca. 15-20 m and emergent trees of ca. 25-30 m, such as Ceiba pentandra, Maquira coriacea, and Schizolobium parahyba. In this zone, the forest edge and canopy are often covered by lianas, whereas the understory is dominated by smaller trees such as Gustavia poeppigiana. Although generally not affected by seasonal flooding, the terra firme zone closest to the Madeira harbors a flora that differs markedly from the more widespread upland areas away from the river (Moser et al., 2014), possibly due to higher soil fertility, canopy openness, and water availability in the zone adjacent to the river. Two observation points (Fa, TA1) corresponding to the lower várzea clustered together with high similarity, while four observation points classified as transitional vegetation types showed higher affinity with Open Ombrophilous Forest (TA2-TA5; Fig. 6). 


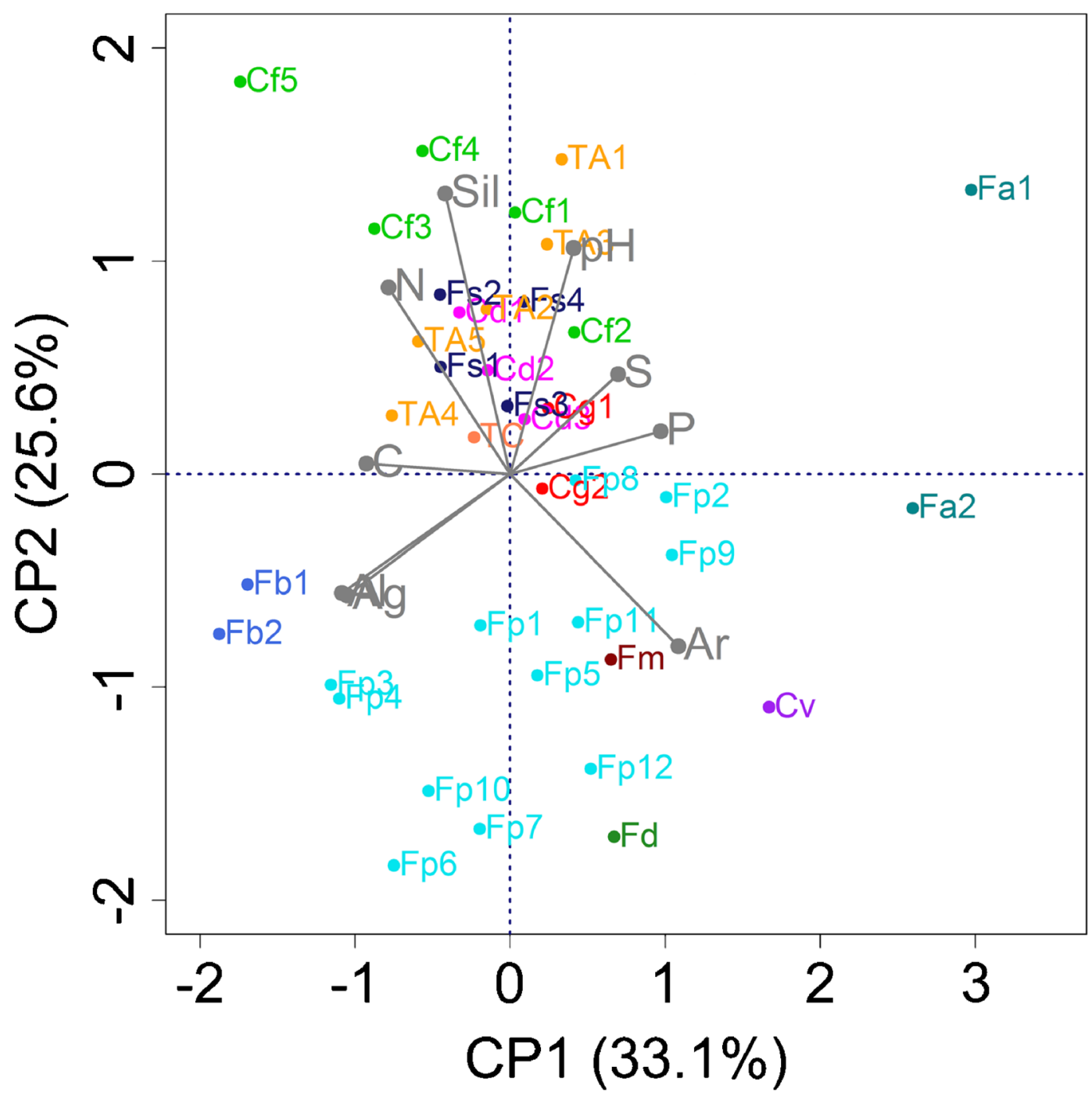

Fig. 5. Principal component analysis of soil parameters collected at 37 observation points in the upper Madeira region (see Table 1 for abbreviations). The two axes explained 59\% of data variance. Strength of correlation between soil variables and PCA axes is depicted in gray. Soil variables: Ag: clay. Al: Aluminium. Ar: sand. C: Carbon. N: Nitrogen. P: Phosphorus, S: Sum of bases, Sil: silt. Ag and $\mathrm{Al}$ appear superimposed in the figure

Dense Ombrophilous Forest (Floresta

Ombrófila Densa, denSE terRa firme Forest)

Dense Ombrophilous Forest is uncommon in the upper Madeira region and was recorded here at only one observation point east of Jaci-Paraná (Fig. 1), where it occurred on flat terrain with well-drained sandy soil of intermediate fertility. This vegetation type presented a tall canopy $25-$ $30 \mathrm{~m}$ high, with an average canopy openness of only $13 \%$ (Table 1 ). The most common tree species recorded were Copaifera multijuga,
Eschweilera coriacea and Theobroma speciosum. Emergent individuals of Dinizia excelsa, Peltogyne heterophylla and Pseudopiptadenia psilostachya were also encountered. Babassu palm (Attalea speciosa), which was very frequent in the sampled Open Ombrophilous Forest, was not found here, while Astrocaryum aculeatum and Euterpe precatoria were occasional. The understory was dominated by young individuals of various tree species and a few shrubs and herbs such as Piper spp. and small palms such as Bactris elegans. 


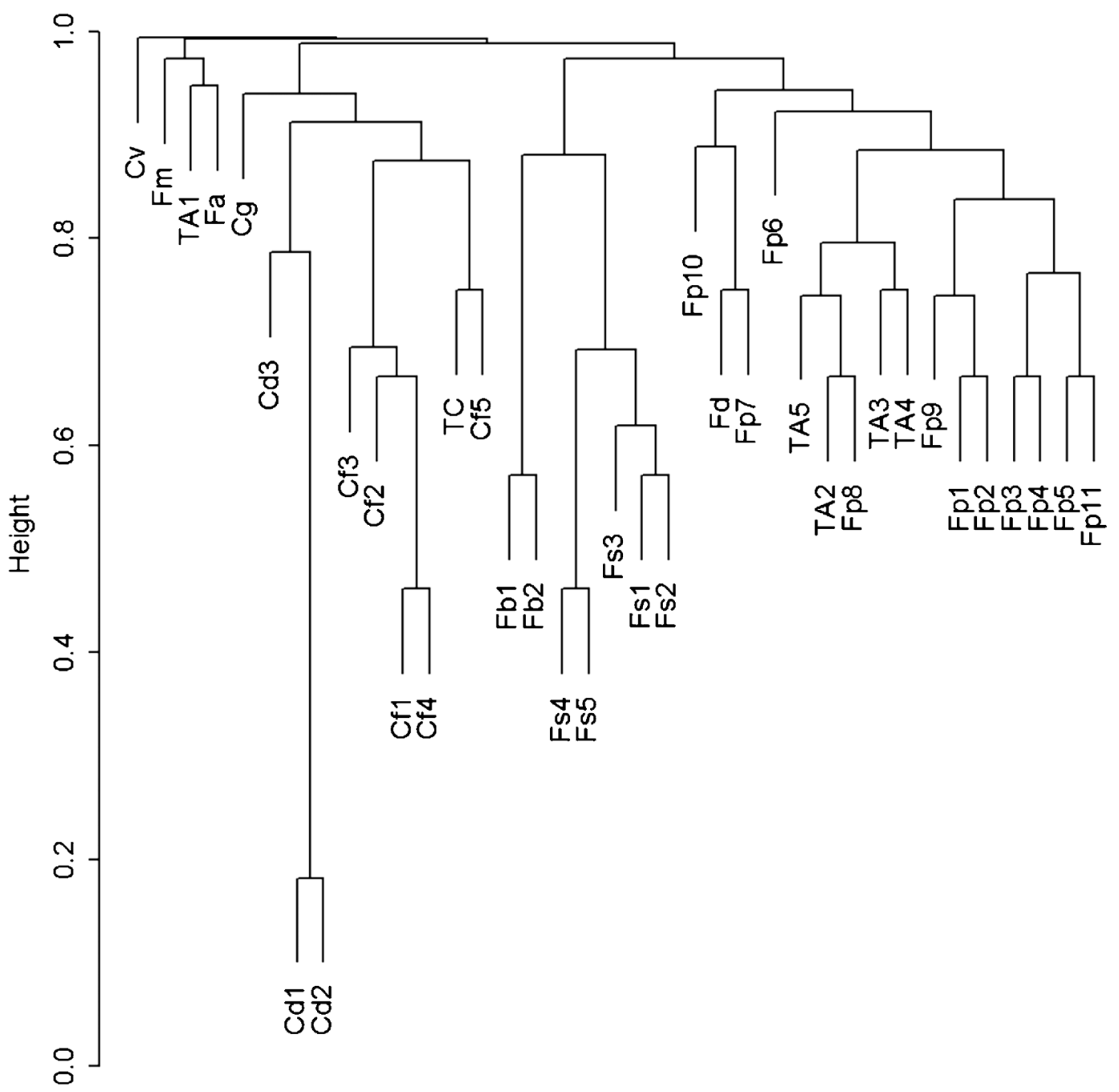

Fig. 6. UPGMA dendrogram of 37 observation points in the upper Madeira region based on analysis of occurrence data (Jaccard similarity index) for the ten most abundant species in each observation point. See Table 1 for abbreviations

Open OMBrophilous Forest (Floresta OMbrófila ABERTA, OPEN TERRA FIRME FOREST)

According to IBGE (2012), the "open" nature of Open Ombrophilous Forest is strongly related to the presence of elements such as palms, sororoca, bamboo and lianas. Depending on the prevalence of these elements, Open Ombrophilous Forest can be subdivided into three subtypes. The subtype "with palms" is the most frequent in Amazonia and in some regions it is known as "babassu forest" due to high abundance of Attalea speciosa. The subtype "with sororoca" is found in temporarily flooded depressions. It is reported as forming extensive patches in the middle course of the
Xingu River in Pará, and in smaller patches on undulating terrain over oxisols in the states of Amazonas, Rondônia, and Roraima, but its distribution is not easily mappable on a regional scale (IBGE, 2012). The subtype "with bamboo" occurs mainly in southwestern Amazonia, with species of the genus Guadua forming large patches of "bamboo forest" (Carvalho et al., 2013). Open Ombrophilous Forest was the most frequently encountered vegetation type in the study area, comprising 18 of 37 observation points. The distinctiveness of the Open Ombrophilous Forest subtypes was supported by the UPGMA analysis, where plots corresponding to the three subtypes grouped into different clusters, and with bamboo 
and sororoca subtypes showing higher similarity (Fig. 6). The three Open Ombrophilous Forest subtypes are described as follows.

Open Ombrophilous Forest with palms (Floresta Ombrófila Aberta com palmeiras).- - This was the most common subtype of Open Ombrophilous Forest in the study area. As the name suggests, it can be distinguished from other subtypes by the high density of trunked palms, with a predominance of babassu palm (Attalea speciosa) in the tree stratum, along with other species of palms that appear less frequently such as Astrocaryum murumuru, Oenocarpus spp., and Euterpe precatoria (Fig. 2C). This vegetation type occurrs on flat terrain or on gentle slopes, on well-drained clayey soils, normally without rocks. Soils that support this subtype tend to be more acidic and less fertile than those that support other vegetation types, while the level of the water-table remains deeper throughout the year (Fig. 4). Open Ombrophilous Forest with palms has an average canopy height of 20-25 m, with emerging trees reaching 30-35 m, and canopy openness of 10$18 \%$ (Table 1). In the tree layer, the most common species were Attalea speciosa, Eschweilera coriacea, Neea floribunda and Rhodothyrsus macrophyllus. Among the emergent species were Bertholletia excelsa, Hevea brasiliensis, H. guianensis, and Peltogyne heterophylla. However, the occurrence and abundance of species in this subtype varied substantially between observation points, mainly due to the high incidence of rare species. Among the herbaceous species, Olyra spp. and the fern Trichomanes pinnatum were the most common, whereas bamboo, lianas and sororoca were generally infrequent.

Open Ombrophilous Forest with sororoca (Floresta Ombrófila Aberta com sororoca).-The Open Ombrophilous Forest with sororoca is characterized by the high frequency of Phenakospermum guyannense, an essentially arborescent herb that can reach $10 \mathrm{~m}$ height (Fig. 2D). This vegetation subtype was observed on the right margin of the Madeira (Fig. 1) in a flat lowland area formed by alluvial deposits that may be occasionally flooded. Soils have claysilty texture, high $\mathrm{pH}$ (Fig. 5; Appendix 1), and the shallowest water-table level among the subtypes of Open Ombrophilous Forest (Fig. 4). The vegetation structure varied little in comparison with the Open Ombrophilous Forest with palms, although the canopy is slightly lower, with an average height of 15-20 m and emergent trees around
25-30 m. Floristic composition differed notably from the previous subtype, the most common species being Miconia eriocalyx, Oenocarpus bataua, Protium spp., Sacoglottis mattogrossensis, Tachigali poeppigiana, and Virola calophylla, as well as the emergent species Qualea paraensis and Erisma bracteosum. Eschweilera coriacea, Hevea brasiliensis and Neea floribunda, which were frequent in the Open Ombrophilous Forest with palms, were encountered only occasionally in this subtype. The understory consisted of young trees and relatively few shrubs. The most common herbaceous species were Ischnosiphon arouma, Olyra spp. and sororoca, as noted. Babassu palm and bamboo were sparse.

Open Ombrophilous Forest with bamboo (Floresta Ombrófila Aberta com bambu).- Open Ombrophilous Forest with bamboo was recorded at only two observation points in hilly sites on the left bank of the Madeira (Fig. 1) over well-drained clayey soil without rocks. The water table levels at these sites showed the greatest annual changes in amplitude among the sites analysed, with very deep levels during the dry season followed by a sharp increase at the beginning of the rainy season (Fig. 3). The average height of the vegetation was 15-20 m, with emergent trees of 25-30 m, and canopy openness around $17 \%$, mostly due to the incidence of bamboo stands (Fig. 2E). Palms were occasional in both the canopy and understory. The most common species in the tree layer were Licania spp., Mezilaurus itauba, Miconia punctata, Protium spp. and Tachigali spp., with Vatairea sericea and Qualea paraensis present in the emergent stratum. Species frequent in other Open Ombrophilous Forest subtypes such as Eschweilera coriacea and Tachigali poeppigiana also occurred in bamboo forest. The understory of this subtype was dense, consisting of the bamboo Guadua sp., as well as Olyra sp., and the ferns Adiantum argutum and Trichomanes pinnatum. Sororoca and lianas were found occasionally. Forests dominated by bamboo seem to be expanding their ranges in Amazonia (IBGE, 2012). The causes of such expansion could be related to either favorable environmental change or human-induced disturbances (McMichael et al., 2014). Establishment of bamboo in areas where it was previously absent alters the structure and dynamics of the local plant communities, since bamboo forests have smaller average tree size and density, lower species richness, and increased mortality rates (Griscom et al., 2007; Medeiros et al., 2013). 
Semideciduous Seasonal Forest (Floresta Estacional Semidecidual, dRY Forest)

Semideciduous Seasonal Forest was found in the study area at a single observation point comprising a small patch of vegetation growing on rocky soil (rock cover 50-90\%) surrounded by Open Ombrophilous Forest (Fig. 2F). The soil had clay-sandy texture, and $\mathrm{pH}$ and fertility with intermediate values compared to other vegetation types. The canopy was around $10-15 \mathrm{~m}$ tall with emerging trees reaching 20-25 m, and the canopy openness measured 34\% at the end of the rainy season (May 2014), a value that would increase considerably at the end of the dry season. Typical dry forest species were recorded in the tree layer, including Astronium sp., Cedrela fissilis, Handroanthus serratifolius, Hymenaea courbaril and Poeppigia procera. The understory was composed of shrubs, bamboo, herbs and lianas, including Bauhinia spp., Begonia guaduensis, Calathea sp., Metrodorea flavida, Peperomia sp., Piper umbellatum, and Urera baccifera. Epiphytic members of Araceae, Bromeliaceae and Orchidaceae were also common. Despite the humid climate of the region and the lack of prolonged drought, this vegetation type exhibits deciduousness during the short dry season, although the canopy is never completely leafless. At the site where this vegetation type was encountered, the large percentage of granite outcrops and shallow soil probably reduce water availability during the dry season. Similar Semideciduous Forests associated with rocky outcrops were reported in northern Mato Grosso, where low water availability in the dry season was also linked to shallow soils (Sasaki et al., 2010). In that region, the dry forest had a mixed composition of evergreen and deciduous species, and the absence of species typically associated with other forest types on terra firme (Zappi et al., 2011). Seasonally dry forests in the Neotropics are often associated with high-fertility soils on limestone outcrops (Pennington et al., 2000), but that does not seem to be the case here since the soil exhibited low to intermediate fertility (Appendix 1; Fig. 5). Although we encountered it at only a single site, it is likely that semideciduous forests associated with rocky outcrops were previously more extensive in the upper Madeira. The presence of valuable timber species makes this vegetation type an obvious target for logging, and thus we suspect that many areas that formerly supported it are now deforested.

\section{CAmpinarana}

The term campinarana (or campina) is normally used to define a type of stunted vegetation dominated by small trees with thin stems, usually growing on white sands, or less often on hydromorphic soils (podzol) (Daly \& Mitchell, 2000; IBGE, 2012). Campinarana forms extensive and disjunct patches of various sizes surrounded by terra firme forests throughout the Amazon basin (Pires, 1973; Lisboa, 1975; Pires \& Prance, 1985; Adeney et al., 2016). Although they display wide structural and floristic variation, ranging from open grassy fields to closed forests, campinaranas encompass a gradient in vegetation structure with some common features, including the predominance of shrubs and small trees, reduced biomass, high incidence of light in the understory, and seasonal flooding (Rodrigues, 1961; Anderson, 1981; Coomes \& Grubb, 1996).

The campinaranas encountered in the present study occupied large flat lowland areas along the right bank of the upper Madeira basin (Fig. 1) and are locally known as "umirizal" (Fernandes \& Guimarães, 2001). These campinaranas share both similarities and differences with campinaranas in other parts of Amazonia, such as those found in the floodplains of the Negro, Orinoco, and Branco river basins (e.g., Anderson, 1981). Similarities include the occurrence of seasonal flooding by elevation of the water table, vegetation structure composed of small trees and often a dense herbaceous cover, low species richness and strong dominance of a few species. However, a key difference in the upper Madeira campinaranas is the predominance of soils composed by fine alluvial (silty) sediments, which contrasts with the sandy soils (often white sand) that support campinarana (or "white-sand forest") elsewhere (Adeney et al., 2016). Plant genera previously referred to as indicators for campinarana (e.g., Byrsonima, Clusia, Pagamea, Tovomita; see Pires \& Prance, 1985; Daly \& Mitchell, 2000) were recorded at campinarana sites sampled in the present study. However, Ruizterania retusa, the dominant species in the tree layer of the campinaranas studied here, 
has not previously been considered to be an indicator species for campinarana (Pires \& Prance, 1985), although it was recorded in the campinaranas of the Viruá National Park in Roraima (Cordeiro et al., 2016). Our findings reinforce the view that the campinaranas encompass heterogeneous species assemblages and physical conditions accross Amazonia (Adeney et al., 2016; Daly et al., 2016).

Water table levels at the campinarana sites surveyed were typically shallow ( $<4 \mathrm{~m}$ deep) throughout the year, with 4-5 month of flooding during the rainy season (Fig. 4). It must be stressed that water saturation in the campinarana sites was caused by the rise of the water table and not by flooding from nearby rivers, although rarely (as was the case with the exceptional floods of 2013/2014) campinaranas in the study area can be inundated by the Madeira.

The campinaranas surveyed formed a vegetation gradient ranging from open grasslands dominated by Cyperacae and Poaceae to closed canopy forests with a canopy height of 10-20 m. Slight differences in topography, and consequently in the duration of flooding appear to be important in structuring the floristic gradient in campinaranas, from open formations in the low-lying areas to forested formations in uplands. Such fine scale topographic variations are also critical in the transitions between flood-tolerant campinaranas and flood-sensitive terra firme forests. Despite substantial structural and floristic differences, most observation points classified as campinaranas clustered into a large group (Fig. 6). Based on structural and floristic variation, and following the classification system adopted here (IBGE, 2012), the campinaranas in the study area were divided into four subtypes: Forested, Wooded, Shrubby, and Grassy-woody Campinarana (Table 1).

Forested Campinarana (Campinarana Florestada).-Forested Campinarana was the subtype with highest vertical structure (Fig. 3A). Its soils exhibited the highest proportion of silt registered in this study, as well as high concentrations of nitrogen and high $\mathrm{pH}$ (Fig. 5). This vegetation type was subject to seasonal flooding and had canopy height ranging from 8 to $20 \mathrm{~m}$, an average canopy openness of $25 \%$ (Table 1). The mostly commonly encountered tree species was Ruizterania retusa, which represented up to onethird of the individuals in a given area. Other commonly encountered trees were Euterpe precatoria, Iryanthera juruensis, Pera decipiens, Tachigali tinctoria, Meriania urceolata, Ouratea spp., Vochysia ferruginea, V. vismiifolia and Xylopia neglecta. The herbaceous layer for this subtype was the least developed among the campinarana subtypes due to lower light penetration in the understory. A high frequency of epiphytes of Araceae and Orchidaceae were found, often associated with ants that make nests in the roots of epiphytes (e.g., Anthurium gracile), forming "ant gardens". Transitional areas between Forested Campinarana and Open Ombrophilous Forest, which are only partially affected by water saturation, were taller and exhibited a more closed canopy and higher species diversity relative to Forested Campinarana. Ruizterania retusa was observed to be less prevalent in these transitional areas, which harbored a mixture of both terra firme species (e.g., Eschweilera coriacea, Hymenaea parvifolia, Licania spp., Peltogyne heterophylla) and campinarana species (e.g., Euterpe precatoria, Garcinia macrophylla, Iryanthera juruensis, Xylopia neglecta).

Wooded Campinarana (Campinarana Arborizada).- This subtype comprises an intermediate form between Forested and Shrubby Campinarana. In the study area it was found to occur on flat terrain subject to seasonally flooding, and was characterized by the high incidence of small hummocks around $1 \mathrm{~m}^{2}$ in area and $40 \mathrm{~cm}$ high. These small elevations in the terrain provided a dry refuge where trees establish, whereas the lower areas between mounds remained flooded for most of the year and were colonized by herbaceous species (Fig. 3D). Wooded Campinarana differed from Forested Campinarana by having smaller ( 3 to $5 \mathrm{~m}$ tall) and more scattered trees with a canopy openness around $42 \%$ (Fig. 3C), and lower species richness. The predominant species encountered was Ruizterania retusa, accounting for up to half the number of stems. Other common species were Byrsonima punctulata, Clusia sp., Henriettea granulata, Miconia prasina, and Tachigali tinctoria. The palm tree Mauritiella armata was occasionally found, while Mauritia flexuosa was rare. A dense herbaceous layer was found, dominated by species of Cyperaceae such as Scleria stipularis and Rhynchospora cephalotes, and species of Eriocaulaceae such as Syngonanthus biformis and S. longipes.

Shrubby Campinarana (Campinarana Arbustiva).-This subtype was found at a single site where it occurred as a patch of low vegetation next to a stream subject to flooding by seasonal 
elevation of the water table. This was the only campinarana registered on white-sand soil, and it was markedly distinct from other sites supporting campinarana in both soil properties (Fig. 5) and species composition (Fig. 6). This essentially open formation was composed mainly of shrubs and herbs, with discontinuous structure ranging from pure herbaceous cover to large aggregates of shrubs and small trees, with a canopy height of 1-2 m (Fig. $3 \mathrm{E})$ and a few larger individuals reaching $4 \mathrm{~m}$. The canopy was observed to be quite open, ranging from $70-100 \%$ open (Table 1). Among woody species encountered were Byrsonima melanocarpa, Caraipa savannarum, Jacaranda campinae, Macairea radula and Ouratea spruceana. The dense herbaceous stratum was dominated by Poaceae, Eriocaulaceae and Xyridaceae, including Bulbostylis sp., Comanthera xeranthemoides, Eragrostis maypurensis, Paepalanthus polytrichoides, Syngonanthus bisumbellatus, S. bracteosus, S. longipes, Trachypogon spicatus, and Xyris jupicai, as well as Siphanthera cordata and the terrestrial orchid Catasetum cassideum.

Grassy-woody Campinarana (Campinarana Gramineo-lenhosa).- This is a savannah-like formation (Fig. 3F) dominated by herbaceous species, with few scattered trees and shrubs, usually occupying higher ground (mounds). In our area, it was found on silty soils subject to seasonal flooding. Soil fertility exhibited intermediate values in comparison to sites supporting other subtypes of campinarana, with the mounds being slightly more fertile than flat areas (Fig. 5; Appendix 1). Trees and shrubs were mostly $1.5-3 \mathrm{~m}$ tall, with some individuals occasionally reaching 4-8 $\mathrm{m}$. The most common tree species were Guatteria sp., Pterandra arborea and Ruizterania retusa. The palms Mauritiella armata and Mauritia flexuosa were also recorded. The herbaceous layer was dominated by Cyperaceae and Poaceae, such as Bulbostylis sp., Digitaria sp., and Echinolaena inflexa, as well as Palhinhaea camporum, Selaginella asperula, Syngonanthus biformis, and S. humboldtii.

\section{Conclusions}

The vegetation surveyed in the study area showed major structural and floristic variation, which permitted the recognition of a number of physiognomies that varied in stature, canopy openness and dominant species. Field observations allowed the recognition of unique suites of indicator species that occurred in high densities in each of the vegetation types surveyed. In addition to vegetation structure and composition, physical and chemical properties of soil and drainage were additional parameters that contributed to our classification of vegetation types. Observation points varied widely in terms of soil texture, fertility, and seasonal variation in groundwater levels between physiognomies. Seasonal flooding appears to be a major driver of floristic composition and structure at the sites where it occurs. Resolution of high levels of environmental and floristic heterogeneity, on both local and regional scales, such as detected in this study would undoubtedly be obscured in studies based solely on satellite imagery.

This survey improves floristic knowledge of a poorly known, athough potentially species-rich Amazonian region. Recent taxonomic work targeting specific groups in our study area has uncovered high taxonomic diversity (Catenacci \& Simon, 2017) and new species (Sobral et al., 2015; Sobral \& Souza, 2017). The data presented here should inform conservation strategies in the region, such that attention is given to the full range of vegetation types, thus encompassing the landscape and biotic diversity of the region as a whole.

\section{Acknowledgments}

We thank Antônio ("Tonico") Barreto dos Santos, Flávio Rodrigues, Glocimar PereiraSilva, Pamela Moser and Washington Oliveira for their help during field work, Bruno Walter for his critical review of an early version of the manuscript, and Aelton Giroldo for support with data analysis. We are indebted to Benjamin Torke and Douglas Daly for their valuable suggestions on the paper. This research is part of first author's masters dissertation in the Department of Botany at the University of Brasília. The research was supported by a scholarship from CAPES (Coordenação de Aperfeiçoamento de Pessoal de Nível Superior). This study is part of the project "Programa de Conservação da Flora na UHE Jirau" funded by Energia Sustentável do Brasil-ESBR. 


\section{Appendix 1}

Table 2. Soll properties for 37 observation points SuRVeyed in the UPPER Madeira River, Rondônia. VAlues Represent the aVERAGE OF A COMPOSITE SAMPLE AT FOUR DEPTHS IN EACH OBSERVATION POINT. VARIABLE UNITS: SILT, CLAY, SAND (G/KG); C, N (G/KG); $\mathrm{AL}^{3+}$, $\mathrm{CA}^{2+}, \mathrm{K}^{+}, \mathrm{MG}^{2+}, \mathrm{NA}^{+}, \mathrm{S}\left(\mathrm{CMOLC} / \mathrm{DM}^{3}\right) ; \mathrm{P}^{+}\left(\mathrm{MG}^{2} / \mathrm{DM}^{3}\right)$.

\begin{tabular}{|c|c|c|c|c|c|c|c|c|c|c|c|c|c|}
\hline Obs. point* & Silt & Clay & Sand & $\mathrm{pH}$ & $\mathrm{Ca}^{2+}$ & $\mathrm{Mg}^{2+}$ & $\mathrm{K}^{+}$ & $\mathrm{Na}^{+}$ & $\mathrm{S}$ & $\mathrm{Al}^{3+}$ & $\mathrm{C}$ & $\mathrm{N}$ & $\mathrm{P}^{+}$ \\
\hline Fal (low) & 344 & 238 & 419 & 5.95 & 5.73 & 2.08 & 0.26 & 0.08 & 8.13 & 0.00 & 4.65 & 0.62 & 85.40 \\
\hline Fa2 (high) & 56 & 281 & 663 & 5.15 & 8.18 & 2.73 & 0.23 & 0.09 & 11.22 & 0.53 & 12.80 & 0.44 & 45.35 \\
\hline $\mathrm{Fd}$ & 50 & 344 & 606 & 3.83 & 1.73 & 0.18 & 0.29 & 0.03 & 2.19 & 3.30 & 14.95 & 0.56 & 4.93 \\
\hline Fp1 & 197 & 475 & 329 & 4.10 & 4.05 & 0.55 & 0.11 & 0.01 & 4.72 & 3.88 & 15.00 & 1.88 & 1.08 \\
\hline Fp2 & 256 & 213 & 532 & 4.30 & 4.48 & 0.70 & 0.15 & 0.01 & 5.34 & 1.58 & 11.73 & 1.91 & 2.33 \\
\hline Fp3 & 234 & 594 & 172 & 4.20 & 0.48 & 0.10 & 0.01 & 0.01 & 0.60 & 5.38 & 24.53 & 1.40 & 1.00 \\
\hline Fp4 & 242 & 625 & 133 & 4.15 & 0.30 & 0.10 & 0.06 & 0.01 & 0.47 & 5.28 & 20.25 & 1.12 & 3.05 \\
\hline Fp5 & 250 & 325 & 425 & 4.08 & 0.23 & 0.10 & 0.04 & 0.01 & 0.37 & 5.13 & 18.38 & 1.13 & 27.13 \\
\hline Fp6 & 131 & 619 & 250 & 3.38 & 0.78 & 0.18 & 0.22 & 0.03 & 1.19 & 4.38 & 21.65 & 0.58 & 3.90 \\
\hline Fp7 & 119 & 463 & 419 & 4.05 & 0.28 & 0.13 & 0.09 & 0.02 & 0.51 & 5.20 & 14.33 & 0.52 & 1.43 \\
\hline Fp8 & 321 & 306 & 373 & 4.25 & 4.80 & 0.90 & 0.10 & 0.01 & 5.56 & 2.88 & 10.28 & 2.01 & 2.80 \\
\hline Fp9 & 271 & 175 & 554 & 4.08 & 4.53 & 0.63 & 0.07 & 0.01 & 5.23 & 2.50 & 7.73 & 1.53 & 1.88 \\
\hline Fp10 & 111 & 456 & 433 & 4.85 & 0.45 & 0.15 & 0.09 & 0.01 & 0.70 & 7.78 & 24.95 & 0.52 & 10.23 \\
\hline Fp11 & 224 & 350 & 426 & 5.03 & 0.40 & 0.10 & 0.07 & 0.03 & 0.60 & 4.08 & 7.30 & 0.44 & 0.63 \\
\hline Fp12 & 156 & 313 & 531 & 4.08 & 1.50 & 0.10 & 0.08 & 0.02 & 1.70 & 4.18 & 10.75 & 0.41 & 2.20 \\
\hline Fs1 & 501 & 344 & 156 & 5.05 & 0.30 & 0.15 & 0.14 & 0.01 & 0.60 & 4.13 & 21.20 & 1.40 & 2.48 \\
\hline $\mathrm{Fs} 2$ & 508 & 331 & 161 & 5.05 & 0.23 & 0.13 & 0.19 & 0.01 & 0.55 & 3.68 & 14.83 & 2.53 & 0.60 \\
\hline $\mathrm{Fs} 3$ & 401 & 344 & 256 & 5.25 & 0.20 & 0.10 & 0.14 & 0.01 & 0.45 & 3.50 & 13.58 & 1.40 & 0.98 \\
\hline Fs 4 & 555 & 256 & 189 & 5.23 & 0.23 & 0.13 & 0.13 & 0.01 & 0.49 & 3.25 & 11.45 & 1.22 & 1.05 \\
\hline $\mathrm{Fb} 1$ & 260 & 669 & 71 & 4.38 & 0.63 & 0.10 & 0.03 & 0.01 & 0.76 & 5.28 & 30.88 & 2.47 & 0.50 \\
\hline $\mathrm{Fb} 2$ & 265 & 688 & 48 & 4.18 & 0.55 & 0.10 & 0.01 & 0.01 & 0.67 & 5.45 & 38.45 & 1.95 & 0.80 \\
\hline $\mathrm{Fm}$ & 144 & 400 & 456 & 4.50 & 2.58 & 0.33 & 0.40 & 0.03 & 3.33 & 2.20 & 15.80 & 0.56 & 4.25 \\
\hline Cf1 & 552 & 250 & 198 & 5.50 & 0.38 & 0.15 & 0.15 & 0.01 & 0.68 & 3.35 & 8.88 & 2.34 & 3.08 \\
\hline Cf2 & 434 & 231 & 335 & 5.45 & 0.25 & 0.15 & 0.17 & 0.01 & 0.58 & 2.90 & 12.00 & 1.60 & 2.28 \\
\hline Cf3 & 550 & 388 & 63 & 5.38 & 0.20 & 0.10 & 0.18 & 0.01 & 0.49 & 3.63 & 28.85 & 2.42 & 1.83 \\
\hline Cf4 & 559 & 313 & 129 & 5.65 & 0.25 & 0.13 & 0.12 & 0.01 & 0.50 & 2.90 & 30.10 & 2.81 & 4.03 \\
\hline $\mathrm{Cf} 5$ & 537 & 344 & 119 & 4.50 & 3.75 & 0.93 & 0.12 & 0.01 & 4.80 & 2.68 & 61.88 & 5.84 & 1.35 \\
\hline $\mathrm{Cd} 1$ & 595 & 350 & 56 & 4.40 & 4.05 & 0.75 & 0.14 & 0.01 & 4.95 & 3.80 & 11.00 & 1.71 & 1.65 \\
\hline $\mathrm{Cd} 2$ & 529 & 319 & 153 & 4.30 & 3.83 & 0.65 & 0.12 & 0.02 & 4.61 & 3.40 & 14.95 & 1.58 & 1.33 \\
\hline $\mathrm{Cd} 3$ & 494 & 331 & 175 & 5.00 & 0.20 & 0.10 & 0.04 & 0.01 & 0.35 & 3.35 & 8.35 & 0.44 & 0.23 \\
\hline $\mathrm{Cv}$ & 75 & 113 & 813 & 4.58 & 1.70 & 0.10 & 0.04 & 0.01 & 1.85 & 1.78 & 16.53 & 0.41 & 5.18 \\
\hline Cg1 (low) & 525 & 269 & 206 & 4.55 & 1.38 & 0.10 & 0.17 & 0.05 & 1.70 & 2.48 & 16.85 & 0.46 & 3.88 \\
\hline Cg2 (high) & 469 & 219 & 313 & 4.33 & 1.33 & 0.15 & 0.30 & 0.03 & 4.00 & 4.35 & 18.50 & 0.56 & 2.48 \\
\hline $\mathrm{TA} 1$ & 617 & 313 & 71 & 5.05 & 5.53 & 3.15 & 0.16 & 0.03 & 8.87 & 2.55 & 9.28 & 1.64 & 4.20 \\
\hline TA2 & 495 & 375 & 130 & 5.58 & 0.50 & 0.40 & 0.21 & 0.01 & 1.12 & 4.10 & 6.53 & 1.43 & 1.40 \\
\hline TA3 & 520 & 400 & 80 & 4.90 & 8.18 & 2.28 & 0.20 & 0.09 & 10.74 & 3.93 & 9.45 & 1.75 & 16.38 \\
\hline TA4 & 503 & 431 & 66 & 4.40 & 4.33 & 0.80 & 0.18 & 0.05 & 5.35 & 6.08 & 10.33 & 1.91 & 2.80 \\
\hline TA5 & 547 & 419 & 35 & 4.68 & 4.65 & 1.98 & 0.19 & 0.05 & 6.87 & 5.93 & 8.30 & 1.79 & 3.08 \\
\hline $\mathrm{TC}$ & 430 & 381 & 189 & 4.35 & 4.00 & 0.73 & 0.20 & 0.02 & 4.95 & 3.98 & 13.90 & 1.75 & 1.53 \\
\hline
\end{tabular}

*For observation points $\mathrm{Cg}$ and $\mathrm{Fa}$, soil samples have been collected in both lower and upper parts of terrain and analyzed separately 


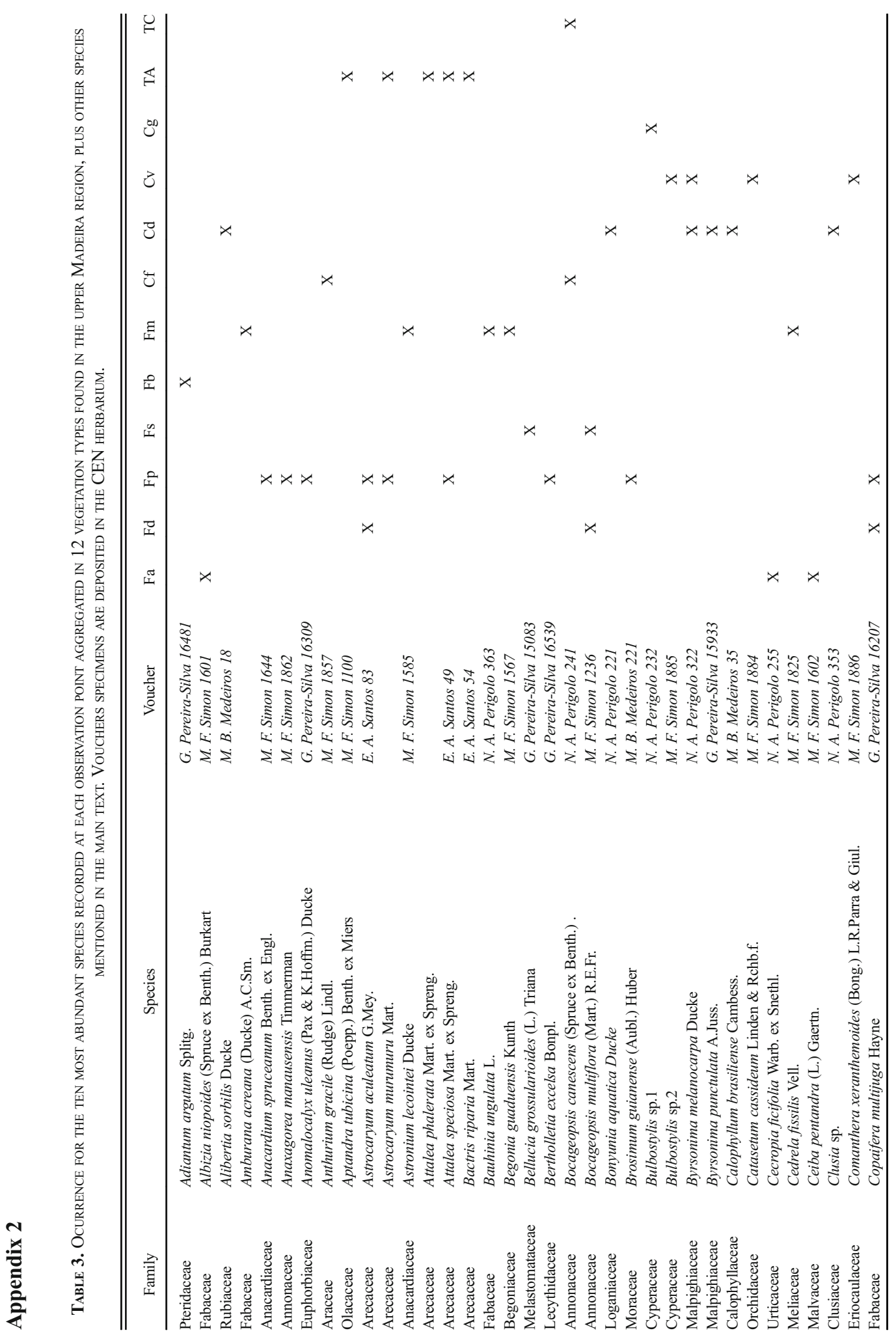




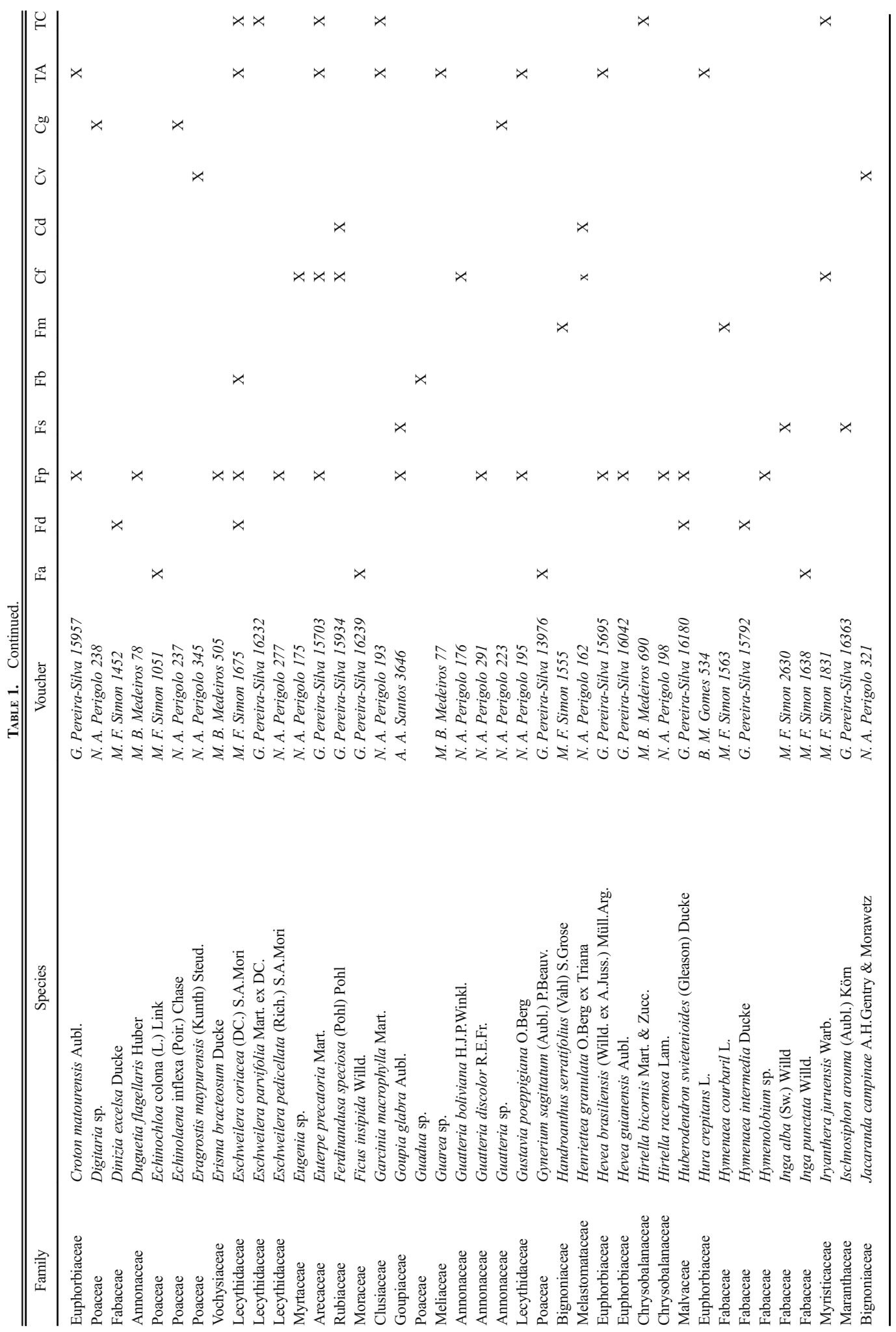




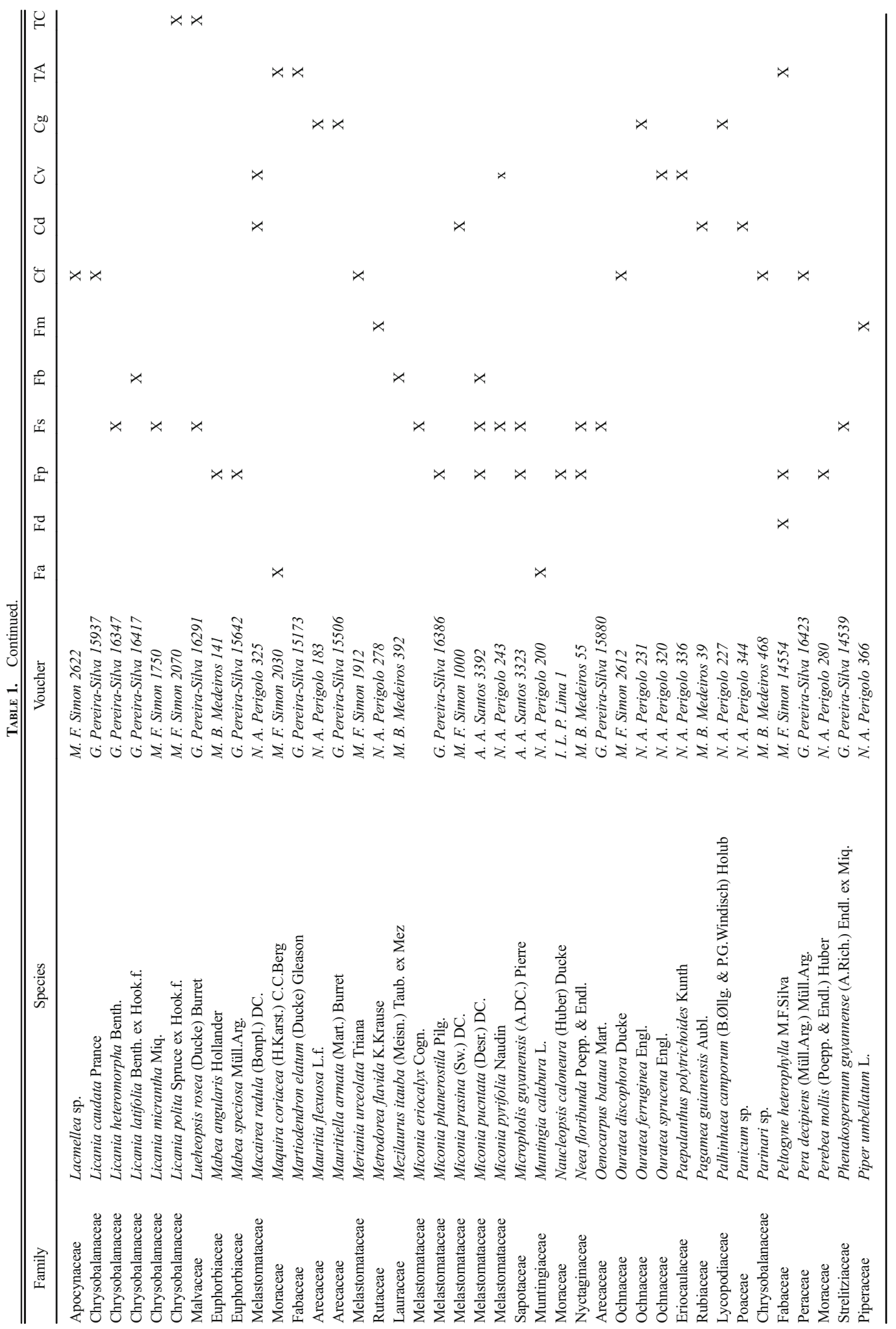




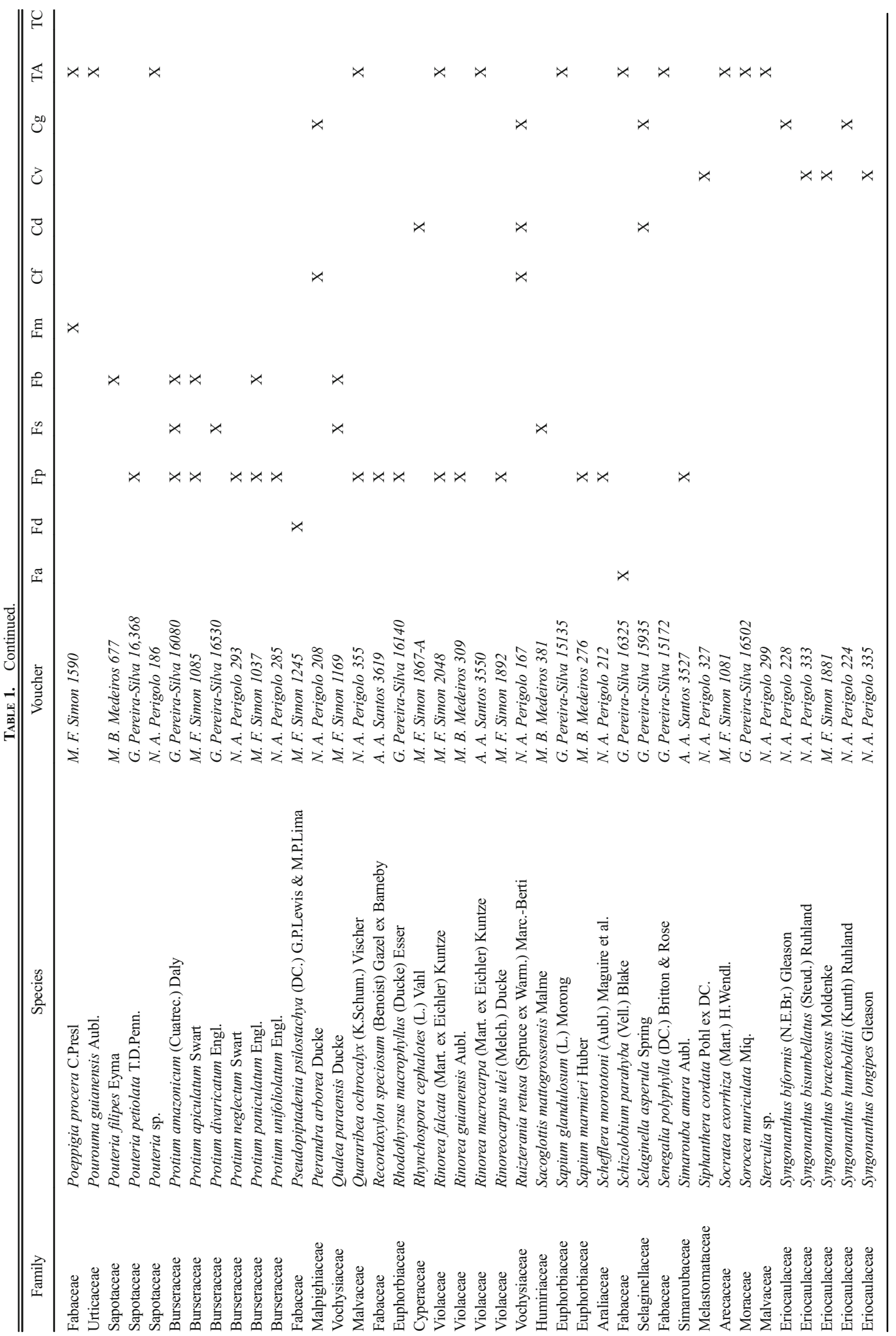




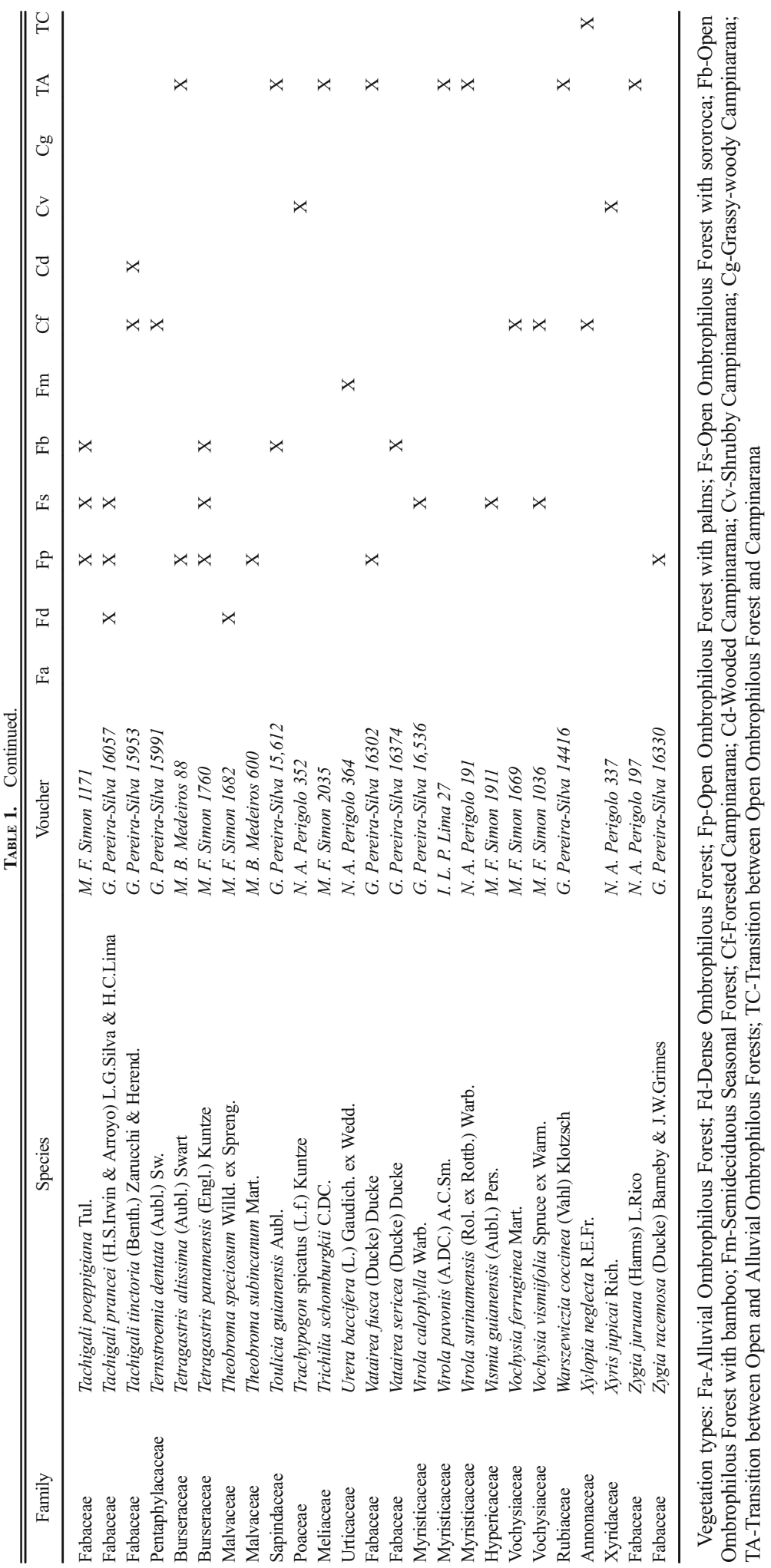




\section{Literature cited}

Abramoff, M. D., P. J. Magalhães \& S. J. Ram. 2004. Image processing with Image J. Biophotonics International 11: 36- 42.

Adeney, M., N. Christensen, A. Vicentini \& M. Cohn-Haft. 2016. White-sand ecosystems in Amazonia. Biotropica 48: $7-23$.

ANA. 2014. Hidro Web Sistemas de informações Hidrológicas. Agência Nacinal de Águas (ANA). http:// hidroweb.ana.gov.br

Anderson, A. B. 1981. White-sand vegetation of Brazilian Amazonia. Biotropica 13: 199-210.

Bohlman, S. A., W. F. Laurance, S. G. Laurance, H. E. M. Nascimento, P. M. Fearnside \& A. Andrade. 2008. Importance of soils, topography and geographic distance in structuring central Amazonian tree communities. Journal of Vegetation Science 19: 863-874.

Braga, P. I. S. 1979. Subdivisão fitogeográfica, tipos de vegetação, conservação e inventário florístico da floresta Amazônica. Acta Amazônica 9: 53-80.

Carleial, S. \& N. C. Bigio. 2014. What survived from the PLANAFLORO project: Angiosperms of Rondônia State, Brazil. Check List 10: 33-45.

Carvalho, A. L., B. W. Nelson, M. C. Bianchini, D. Plagnol, T. M. Kuplich \& D. C. Daly. 2013. Bamboo-dominated forests of the southwest Amazon: Detection, spatial extent, life cycle length and flowering waves. PLoS ONE 8: e54852.

Castilho, C. V., W. E. Magnusson, R. N. O. Araújo, R. C. C. Luizão, F. J. Luizão, A. P. Lima \& N. Higuchi. 2006. Variation in aboveground tree live biomass in a central Amazonian forest: Effects of soil and topography. Forest Ecology and Management 234: 85-96.

Catenacci, F. S. \& M. F. Simon. 2017. A checklist of Lecythidaceae in the upper Madeira River, Rondônia, Brazil with comments on diversity and conservation. Brittonia (online). https://doi.org/10.1007/s12228-0179482-4.

Cochrane, T. T. \& T. A. Cochrane. 2006. Diversity of the land resources in the Amazonian State of Rondônia, Brazil. Acta Amazônica 36: 91-101.

Coomes, D. A. \& P. J. Grubb. 1996. Amazonian caatinga and related communities at La Esmeralda, Venezuela: Forest struture, physiognomy and floristics, and control soil factors. Vegetatio 122: 167-191.

Cordeiro, C. L., D. F. Rossetti, R. Gribel, H. Tuomisto, H. Zani, C. A. Ferreira \& L. Coelho. 2016. Impact of sedimentary processes on white-sand vegetation in an Amazonian megafan. Journal of Tropical Ecology 32: 498-509.

Daly, D. C. \& J. D. Mitchell. 2000. Lowland vegetation of tropical South America. Pp. 391-453. In: D. L. Lentz (ed.), An imperfect balance: Landscape transformations in the pre-Columbian Americas. Columbia University Press, New York.

_., M. Silveira, H. Medeiros, W. Castro, \& F. A. Obermüller. 2016. The white-sand vegetation of Acre, Brazil. Biotropica, 48: 81-89.

Ducke, A. \& G. A. Black. 1954. Notas sobre a fitogeografia da Amazônia brasileira. Boletim Técnico do Instituto Agronômico do Norte 29: 1-62.
Eiten, G. 1992. Natural Brazilian vegetation types and their causes. Anais da Academia Brasileira de Ciências 64: 3565.

EMBRAPA. 1997. Manual de Métodos de Análise de Solo. Centro Nacional de Pesquisa de Solos - EMBRAPA, Rio de Janeiro, Brazil.

Faria, J. C \& C. G. B. Demetrio. 2011. bpca: Biplot of multivariate data based on Principal Components Analysis. ESALQ, USP, Brazil.

Fernandes, L. C. \& S. C. P. Guimarães. 2001. Atlas geoambiental de Rondônia. Secretaria de Estado do Desenvolvimento Ambiental, Porto Velho, Brazil.

Ferraz, S. F. D. B., C. A. Vettorazzi, D. M. Theobald \& M. V. R. Ballester. 2005. Landscape dynamics of Amazonian deforestation between 1984 and 2002 in central Rondônia, Brazil: Assessment and future scenarios. Forest Ecology Management 204: 69-85.

Gotelli, N. J. \& A. M. Ellison. 2012. A primer of ecological statistics. Sinauer Associates, Sunderland, MA.

Griscom, B. W., D. C. Daly \& M. S. Ashton. 2007. Floristics of bamboo-dominated stands in lowland terra-firma forests of southwestern Amazonia. Journal of the Torrey Botanical Society 134: 108-125.

Hopkins, M. J. G. 2007. Modelling the known and unknown plant biodiversity of the Amazon basin. Journal of Biogeography 34: 1400-1411.

IBGE. 2012. Manual técnico da vegetação brasileira. Ministério do Planejamento, Orçamento e Gestão. Instituto Brasileiro de Geografia e Estatística IBGE, Rio de Janeiro.

Junk, W. J., M. T. F. Piedade, J. Schöngart, M. Cohn-Haft, J. M. Adeney \& F. Wittmann. 2011. A classification of major naturally-occurring Amazonian lowland wetlands. Wetlands 31: 623-640.

Kottek, M., J. Grieser, C. Beck, B. Rudolf \& F. Rubel. 2006. World map of the Köppen-Geiger climate classification updated. Meteorologische Zeitschrift 15: 259-263.

Lisboa, P. L. B. 1975. Estudos sobre a vegetação das campinas amazônicas - II, Observações gerais e revisão bibliográfica sobre as campinas amazônicas de areia branca. Acta Amazonica 5: 211-233.

McMichael, C. H., M. W. Palace \& M. Golightly. 2014. Bamboo-dominated forests and pre-Columbian earthwork formations in southwestern Amazonia. Journal of Biogeography 41: 1733-1745.

Medeiros, H., W. Castro, C. I. Salimon, I. B. Silva \& M. Silveira. 2013. Tree mortality, recruitment and growth in a bamboo dominated forest fragment in southwestern Amazonia, Brazil. Biota Neotropica 13: 29-34.

Milliken, W., D. Zappi, D. Sasaki, M. Hopkins \& R. T. Pennington. 2010. Amazon vegetation: How much don't we know and how much does it matter? Kew Bulletin 65 : 691-709.

Moser, P., W. L. Oliveira, M. B. Medeiros, J. R. Pinto, P. V. Eisenlohr, I. L. Lima, G. P. Silva \& M. F. Simon. 2014. Tree species distribution along environmental gradients in an area affected by a hydroelectric dam in southern Amazonia. Biotropica 46: 367-376.

Oksanen, J., F. G. Blanchet, R. Kindt, L. Pierre, P. R. Minchin, R. B. O'Hara, G. L. Simpson, P. Solymos, M. H. H. Stevens, \& H. Wagner. 2016. vegan: Community Ecology Package. R package version 2.4-0.

Oliveira, A. A. 2000. Inventários quantitativos de árvores em matas de terra firme: Histórico com enfoque na Amazônia brasileira. Acta Amazonica 30: 543-567. 
Pennington, R. T., D. A. Prado \& C. Pendry. 2000. Neotropical seasonally dry forests and Pleistocene vegetation changes. Journal of Biogeography 27: 261-273.

Pires, J. M. 1973. Tipos de vegetação da Amazônia. Boletim do Museu Paraense Emílio Goeldi 20: 179-202.

\& G. T. Prance. 1985. The vegetation types of the Brazilian Amazon. Pp. 109-145. In: G. T. Prance \& T. E. Lovejoy (ed.), Key environments: Amazonia. Perganon Press, Oxford.

Prance, G. T. 1980. A terminologia dos tipos de florestas amazônicas sujeitas a inundação. Acta Amazonica 10: 495-504.

Py-Daniel, L. R. 2007. Caracterização da área amostrada. Pp. 35-42. In: L. R. Py-Daniel, C. P. Deus, A. L. Henriques, D. M. Pimpão \& O. M. Ribeiro (eds.), Biodiversidade do médio Madeira: Bases científicas para propostas de conservação. INPA, Manaus.

R Development Core Team. 2014. R: A language and environment for statistical computing. R Foundation for Statistical Computing, Vienna, Austria. http://www.R-project.org

RADAMBRASIL. 1978. Levantamento de recursos naturais vol. 16: Folha SC.20 Porto Velho. Ministério de Minas e Energia, Departamento Nacional da Producão Mineral, Rio de Janeiro.

Rodrigues, W. A. 1961. Aspectos fitossociológicos das caatingas do Rio Negro. Boletim do Museu Paraense Emílio Goeldi 15: 1-41.
Sasaki, D., D. C. Zappi, W. Milliken, G. S. Henicka \& J. H. Piva. 2010. Vegetação e plantas do Cristalino: Um manual. Royal Botanic Gardens, Kew.

Sayre, R., E. Roca, G. Sedaghatkish, B. Young, S. Keel, R. Roca \& S. Sheppard. 2003. Natureza em foco: Avaliação ecológica rápida. Island Press, Washington, DC.

Sneath, P. H. A. \& R. R. Sokal. 1973. Numerical taxonomy. W. H. Freeman, San Francisco.

Sobral, M. \& M. A. D. Souza. 2017. Myrcia incompleta (Myrtaceae), a new species from Amazonian Brazil. Brittonia (online). https://doi.org/10.1007/s12228-0179481-5.

M. A. D. Souza \& B. G. Luize. 2015. Three new northern Brazilian Myrtaceae. Phytotaxa 219: 165-173.

Sousa-Baena, M. S., L. C. Garcia \& A. T. Peterson. 2014. Completeness of digital accessible knowledge of the plants of Brazil and priorities for survey and inventory. Diversity and Distributions 20: 369-381.

ter Steege, H., N. C. A. Pitman, O. L. Phillips, J. Chave, D. Sabatier, A. Duque, J. F. Molino, M. F. Prevost, R. Spichiger, H. Castellanos, P. von Hildebrand \& R. Vasquez. 2006. Continental-scale patterns of canopy tree composition and function across Amazonia. Nature 443: $444-447$.

Zappi, D. C., D. Sasaki, W. Milliken, J. Iva, G. S. Henicka, N. Biggs \& S. Frisby. 2011. Plantas vasculares da região do Parque Estadual Cristalino, norte de Mato Grosso, Brasil. Acta Amazonica 41: 29-38. 